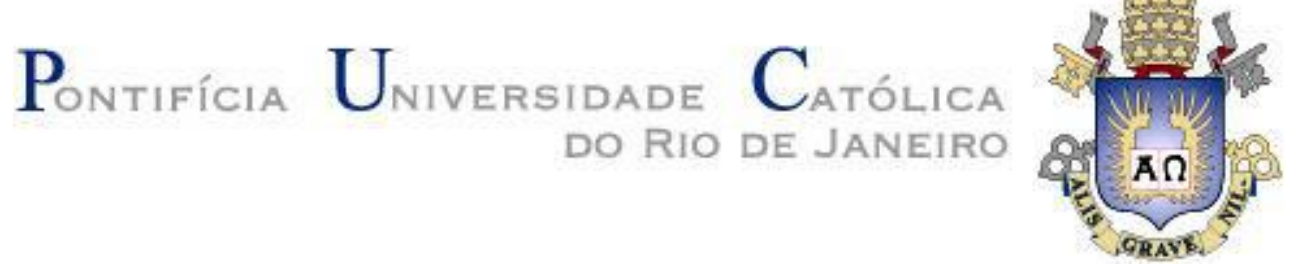

Débora da Silva Sampaio

\title{
A construção do vínculo parento-filial nas adoções tardias
}

\section{Dissertação de Mestrado}

Dissertação apresentada como requisito parcial para obtenção do grau de Mestre pelo Programa de Pósgraduação em Psicologia Clínica do Departamento de Psicologia da PUC-Rio.

Orientadora: Profa. Andrea Seixas Magalhães

Rio de Janeiro

Fevereiro de 2017 
Pontifícia Universidade Católica

\section{Débora da Silva Sampaio}

\section{A construção do vínculo parento-filial nas adoções tardias}

Dissertação apresentada como requisito parcial para obtenção do grau de Mestre pelo Programa de PósGraduação em Psicologia (Psicologia Clínica) do Departamento de Psicologia do Centro de Teologia e Ciências Humanas da PUC-Rio. Aprovada pela Comissão Examinadora abaixo assinada.

Profa. Andrea Seixas Magalhães

Orientadora

Departamento de Psicologia - PUC-Rio

Profa. Lidia Levy de Alvarenga

Departamento de Psicologia - PUC-Rio

Profa. Rebeca Nonato Machado Departamento de Psicologia - CCE/PUC-Rio

Profa. Monah Winograd Coordenadora Setorial de Pós-Graduação

e Pesquisa do Centro de Teologia e Ciências Humanas - PUC-Rio

Rio de Janeiro, 07 de fevereiro de 2017. 
Todos os direitos reservados. É proibida a reprodução total ou parcial do trabalho sem autorização do autor, do orientador e da universidade.

Débora da Silva Sampaio

Graduou-se em psicologia pela Universidade do Estado do Rio de Janeiro em 2014. Atua na área clínica com crianças, adolescentes, adultos e idosos. Possui interesse nos seguintes temas: adoção tardia, parentalidade adotiva, avaliação psicológica, psicanálise e clínica infantil.

Ficha Catalográfica

Sampaio, Débora da Silva

A construção do vínculo parento-filial nas adoções tardias / Débora da Silva Sampaio; orientadora: Andrea Seixas Magalhães. -2017.

$67 \mathrm{f.} ; 30 \mathrm{~cm}$

Dissertação (mestrado)-Pontifícia Universidade Católica do Rio de Janeiro, Departamento de Psicologia, 2017. Inclui bibliografia

1. Psicologia - Teses. 2. Adoção tardia. 3. Parentalidade na adoção. 4. Vínculo parento-filial. 5. Dificuldades. 6. Motivação. I. Magalhães, Andrea Seixas. II. Pontifícia Universidade Católica do Rio de Janeiro. Departamento de Psicologia. III. Título. 


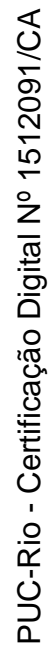

À Gabriela. 


\section{Agradecimentos}

A Deus por ter me sustentado, ter sido minha força e fortaleza, me guardando e direcionando meu caminhar com seu imenso amor.

À minha orientadora, Dra. Andrea Seixas Magalhães, pela dedicação e conhecimento passado ao longo desse percurso, sempre com muito carinho e atenção.

À CAPES pelo incentivo e pela bolsa que possibilitou a realização desse trabalho.

Aos membros da banca, Dra. Lidia Levy de Alvarenga e Dra. Rebeca Nonato Machado pelo interesse e acolhimento a meu trabalho.

Aos professores e funcionários do Departamento de Psicologia da PUC-Rio pelo apoio durante esse processo.

Aos meus pais por acreditarem no meu trabalho, me incentivando com amor incondicional. Sem vocês, nada disso seria possível.

Aos familiares que me apoiaram durante esse percurso.

A Mateus Medeiros pela paciência e por estar ao meu lado durante essa trajetória. Agradeço pela parceria e pelos momentos especiais de grande sintonia.

À Dra. Maria do Carmo Cintra de Almeida Prado, pelo carinho e apoio de sempre, me fazendo acreditar que este trabalho seria possível.

A minha analista, Cecilia Freire Martins, pelo cuidado e pela escuta sensível, me ajudando a ter coragem para seguir.

Aos amigos verdadeiros, pelas conversas e contribuições dadas ao meu trabalho.

À Eliana Bayer Knopman pela receptividade e colaboração para este trabalho.

Aos Grupos de Apoio à Adoção que me receberam e colaboraram com o desenvolvimento dessa pesquisa.

Aos pais que se disponibilizaram e cederam seu tempo, compartilhando comigo suas histórias.

A todos que participaram e contribuíram, direta ou indiretamente, minha sincera gratidão. 


\section{Resumo}

Sampaio, Débora da Silva; Magalhães, Andrea Seixas. A construção do vínculo parento-filial nas adoções tardias. Rio de Janeiro, 2017, 67p. Dissertação de Mestrado - Departamento de Psicologia, Pontifícia Universidade Católica do Rio de Janeiro.

$\mathrm{Na}$ adoção tardia, a criança chega ao novo lar com um histórico, muitas vezes, repleto de rupturas e abandonos. É nesse contexto, com a demanda de reconstruir um ambiente suficientemente bom, além da busca de satisfazer as próprias motivações para uma adoção, que as famílias adotantes de crianças maiores encontrarão desafios importantes na construção do vínculo parento-filial. Esta pesquisa teve por objetivo investigar a construção do vínculo parento-filial nas adoções tardias, levando em consideração as motivações dos pais, as vivências anteriores das crianças, além das fantasias e expectativas relacionadas à criança imaginada. Para alcançar os objetivos propostos, foram entrevistados 10 sujeitos independentes, 3 homens e 7 mulheres, que adotaram crianças maiores de dois anos e as entrevistas analisadas pelo método de análise de conteúdo. Os participantes ressaltaram como principais desafios para construção do vínculo o comportamento agressivo da criança, dificuldades com regras e autoridade, falta de segurança jurídica, atraso escolar e problemas na adaptação à rotina familiar. A vivência da parentalidade se mostrou diretamente relacionada ao sentimento de responsabilidade e à imposição de regras. A principal motivação foi o desejo de ser mãe/pai, além da busca por fazer o bem. As expectativas e fantasias emergiram nas falas ligadas ao medo de não conseguir exercer a função parental de maneira plena. A forma singular como os pais acolheram as dificuldades, integrando passado e presente, de modo a reconstruir o ambiente familiar perdido, bem como o suporte oferecido pela rede, foi fundamental para a construção e manutenção do vínculo parento-filial.

\section{Palavras-chave}

Adoção tardia; parentalidade na adoção; vínculo parento-filial; dificuldades; motivação; expectativas. 


\section{Abstract}

Sampaio, Débora da Silva; Magalhães, Andrea Seixas (Advisor). The construction of the parental-child bond in late adoptions. Rio de Janeiro, 2017, 67p. Dissertação de Mestrado - Departamento de Psicologia, Pontifícia Universidade Católica do Rio de Janeiro.

In late adoption, the child arrives at the new home with a history, often full of ruptures and abandonment. It is in this context, with a demand to build a good enough environment, besides the search to satisfy their own motivations for an adoption, that adoptive families of older children will find important challenges when building a parental-child bond. This research aimed to investigate the construction of the parental-child bond in late adoptions, taking into consideration the parents' motivations, children's previous experiences, and the fantasies and expectations related to the imagined child. In order to achieve the proposed objectives, 10 independent people were interviewed, 3 men and 7 women, who adopted children older than 2 years old. The interviews were analyzed by the content analysis method. Participants emphasized the following as main challenges for the bond construction: the child's aggressive behavior, difficulties with rules and authority, lack of legal certainty, delay in school and problems in the adaptation with family routine. The experience of parenting was found directly related to the feeling of responsibility and the imposition of rules. The main motivation was the desire to be a parent, as well as the desire to do something good. Expectations and fantasies emerged in the speeches linked to the fear of not being able to fully exercise the parental function. The singular way that parents welcomed difficulties, integrating past and present, in order to rebuild the lost family environment, as well as the support network offered was fundamental for the construction and maintenance of the parental-child bond.

\section{Keywords}

Late adoption; Parenting in adoption; Parental-child bond; Difficulties; motivation; Expectations. 


\section{Sumário}

1. Introdução 9

2. Pedras no caminho da adoção tardia: desafios para 14 o vínculo parento-filial

2.1. Método 20

2.2. Resultados e discussão 22

2.3. Considerações finais 34

3. Ser mãe, ser pai na adoção tardia: construção do vínculo 36 parento-filial

3.1. Método 40

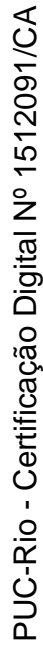

3.2. Resultados e discussão 42

3.3. Considerações finais 53

4. Considerações finais $\quad 55$

5. Referências bibliográficas 58

$\begin{array}{ll}\text { Anexos } & 63\end{array}$ 


\section{1.}

\section{Introdução}

A história nos mostra que a adoção não é uma prática pós-moderna. Tratase de uma prática que vem, ao longo do tempo, recebendo diferentes significações, desde religiosas até políticas. $\mathrm{Na}$ antiguidade, a adoção era valorizada por possibilitar a perpetuação da geração, do nome da família. Já na Idade Média, a Igreja Católica passou a ver com maus olhos essa prática devido à possibilidade de reconhecimento dos filhos gerados em relações adúlteras ou incestuosas. O tema ressurge na Idade Moderna já incluído no código civil (MAUX \& DUTRA, 2010).

Costa \& Rossetti-Ferreira (2007) afirmam que não houve nenhuma época ao longo da história em que não se possa encontrar alguma prática da adoção. Contudo, sua regulamentação legal e prática vêm se constituindo ao longo dos anos a partir de diversas transformações. Dentre as mais antigas formas de adoção, encontram-se, historicamente, no Egito, na Índia, na China, na Grécia e em Roma, estando sua forma mais antiga presente no Código de Hammurabi (2800 a. C.).

Nos países de direito romano, a prática da adoção sempre existiu. Ela passou a representar o principal meio pelo qual se poderia perpetuar o poder, a linhagem de patrimônio e a manutenção das dinastias através da hierarquia passada de geração para geração. Essa prática, com finalidade exclusivamente de atender aos interesses dos adotantes, foi uma tendência que se manteve. Como exemplo, tem-se a linhagem imperial que parte de Otávio, adotado por Júlio César, que reinou por mais de um século através dos descendentes adotivos. Temse ainda o exemplo de Napoleão Bonaparte que também se utilizou das garantias do direito de sucessão dos filhos adotivos, já que sua esposa não podia engravidar. Todavia, a lei que favorecia essa prática era demasiadamente restritiva, uma vez que só era possível adotar pessoas maiores, na ocasião, a partir de vinte e três anos (VARGAS, 2013).

Nos países de direito anglo-saxão, a adoção passou a ser utilizada após a Primeira Grande Guerra. A intenção dessa prática era oferecer pais aos órfãos considerados filhos de heróis pela sociedade. As significações sobre adoção 
durante esse período inicial estavam totalmente voltadas aos interesses dos adultos e das sociedades. Assim, a adoção numa perspectiva mais contemporânea vem ganhando novas significações. O maior interesse está voltado para o bem estar da criança, ou seja, o propósito é encontrar uma família para uma criança e não uma criança para uma família (COSTA \& ROSSETTI-FERREIRA, 2007).

No Brasil, a adoção está presente desde a época colonial, quando a prática do abandono já era recorrente. Durante este período, pode-se destacar a Roda dos Expostos como uma das instituições vinculadas à Igreja que teve maior tempo de duração. Costa \& Rossetti-Ferreira (2007) assinalam que a Roda dos Expostos foi um tipo de assistência, na época, criada para filhos de famílias com baixa condição socioeconômica, vistas como carentes, possíveis delinquentes e que, por isso, precisavam ser educados e controlados. Ela tinha como objetivo recolher crianças abandonadas anonimamente. Esta instituição durou até o ano de 1950, representando durante todo esse tempo praticamente a única instituição de assistência à criança no Brasil. Foi através da possibilidade de mão de obra barata e do cumprimento da função de caridade pregada pela Igreja que a adoção se constituiu no Brasil. Isso porque era comum ter filhos de terceiros como "filhos de criação" em casa, numa prática voltada para a caridade e sem formalização jurídica.

A assistência e o cuidado oferecidos às crianças abandonadas no Brasil vêm sofrendo transformações até os dias atuais. Inicialmente, eram de responsabilidade da Igreja, mais tarde surgiram os profissionais filantropos até chegar à responsabilidade do Estado. O movimento filantrópico surge como novo paradigma no lugar da caridade religiosa e busca se organizar de acordo com as exigências sociais, políticas, econômicas e morais que aparecem no início do século XX (SIQUEIRA \& DELL'AGLIO, 2006).

Juntamente com a República, veio a valorização da infância. Todavia, a atenção à criança vítima só teve espaço a partir dos anos de 1970, quando aumentaram as denúncias a esse respeito. O ano de 1978 ficou conhecido como "Ano Internacional da Criança", levando à criação de associações para tratar dos direitos infantis, o que acabou por influenciar a criação do Estatuto da Criança e do Adolescente (ECA), estabelecido como lei em 1990 (BRASIL, 1990).

O ECA surge como paradigma, priorizando o convívio familiar e preconizando direitos para as crianças e para as famílias. Transforma a visão de 
instituição puramente assistencialista em um lugar que favoreça a socialização e o desenvolvimento infantil. Desta forma, para possibilitar nova maneira de compreender as questões sociais da criança, é preciso primeiramente desconstruir a antiga organização que favorecia a exclusão e abandonar o que já estava instituído para criar uma nova forma de se pensar as necessidades da criança e da família que precisam de assistência (VICENTE, 1999).

De acordo com o ECA, o abrigo está inserido como parte das medidas protetivas, sendo entendido como "medida provisória e excepcional, utilizável como forma de transição para a colocação em família substituta, não implicando privação de liberdade" (BRASIL, 1990, Art.101, VIII). Portanto, observa-se que a perspectiva de reinserção da criança no ambiente familiar se faz prioritária, sendo a função do abrigo mediar este período de transição.

Em 2009, após 19 anos, o ECA ou Lei $n^{\circ} 8.069 / 90$ sofreu sua primeira reforma. A Lei $\mathrm{n}^{\mathrm{o}}$ 12.010, de 03 de agosto de 2009, conhecida como Lei Nacional de Adoção (BRASIL, 2009), promoveu alterações em 54 artigos da primeira Lei, além de promover algumas inovações. A nova Lei tem como principal proposta aperfeiçoar o ECA para que a garantia do convívio familiar, direito de toda criança, seja garantido.

Ao entrar em cena, a Nova Lei Nacional de Adoção busca maior ênfase na importância da reinserção familiar, sendo o prazo máximo de dois anos para que a reinserção aconteça, salvo os casos em que o bem estar das crianças seja permanecer na instituição. De acordo com essa lei, as instituições de acolhimento ficam responsáveis por adotarem o princípio da preservação dos vínculos familiares e da promoção da reintegração familiar. Desta forma, nota-se que a nova lei tem como principal prerrogativa auxiliar as famílias visando promover o restabelecimento do convívio familiar no tempo mais breve possível (SILVA \& ARPINI, 2013).

Contudo, as crianças continuam lotando e permanecendo nos abrigos com idade cada vez mais avançada. No ano de 2016, de acordo com dados estatísticos dos relatórios públicos do Cadastro Nacional de Adoção (CNA), eram 35770 pretendentes disponíveis aguardando pela chegada de um filho, enquanto existiam 4943 crianças e adolescentes disponíveis para adoção. Diante desse quadro, a maioria das crianças que compõem a lista de espera são maiores de dois anos, configurando as chamadas "adoções tardias". Essas adoções são consideradas 
difíceis por uma série de particularidades, dentre elas, o interesse dos brasileiros candidatos à adoção ser, sobretudo, por bebês, de pele clara e do sexo feminino. A literatura tem mostrado que o processo de adoção tardia envolve diversas especificidades e desafios tanto para os pais quanto para as crianças, sobretudo, no que diz respeito ao período inicial de convivência (GHIRARDI, 2009; LEVINZON, 2000; LEVY, PINHO, FARIA, 2009; PEITER, 20011).

A adoção se apresenta como principal forma de reconstrução do ambiente familiar que possa ter se apresentado como falho, negligente e/ou faltoso. Nesse processo, a busca é por uma família que ofereça atenção às necessidades dessa criança com um histórico de perdas e separações tão marcantes. Na maioria das vezes, esse processo se dá no encontro de dois sofrimentos: a perda dos laços primários de uma criança e a desilusão de um casal diante da sua infertilidade. Nesse sentido, Schettini, Amazonas e Dias (2006) demarcam duas finalidades para a adoção: permitir que a criança tenha uma nova família oferecendo ambiente seguro para seu desenvolvimento e possibilitar aos pais o exercício da parentalidade.

Parte-se do pressuposto de que a parentalidade se define como uma reorganização mental vivida pelos pais e que se inicia diante do desejo de ter um filho. O conceito de parentalidade não se reduz à designação como pai e mãe, é necessário “tornar-se pais", e isso só é possível através de um processo complexo que implica níveis conscientes e inconscientes do funcionamento mental. Assim, tornar-se pai e tornar-se mãe tem relação direta com a história individual de cada um dos pais (HOUZEL, 2006; ZORNIG, 2010; MACHADO, 2014).

Nesse contexto, a adoção tardia se configura, muitas vezes, a partir de longo período de institucionalização da criança. Ela traz consigo um histórico repleto de rupturas, abandonos e vivências de violências e abusos de diversos tipos que possa ter tido. Diante disso, podem ter havido falhas ambientais iniciais que irão repercutir na construção de novos vínculos. É nesse contexto, com a demanda de reconstruir um ambiente suficientemente bom e com base na busca por satisfazer as próprias motivações para uma adoção, que as famílias adotantes de crianças maiores encontrarão desafios importantes na construção do vínculo parento-filial.

Abordar o tema da construção do vínculo parento-filial requer atenção aos fatores que podem interferir nesse processo. Dentre esses, observam-se as 
dificuldades no período de adaptação, a relação dos pais com o histórico da criança, questões subjetivas dos pais adotivos relacionadas à vivência da parentalidade, como, por exemplo, motivações, fantasias, expectativas diante da adoção.

A presente pesquisa objetivou investigar a construção do vínculo parentofilial nas adoções tardias. Com relação aos objetivos específicos, buscou-se investigar: as motivações para a escolha da adoção tardia; como as vivências anteriores dos pais e das crianças poderiam repercutir na construção do vínculo parento-filial; as fantasias relacionadas à criança imaginada.

Para tanto, foi realizado um estudo exploratório, por meio de entrevistas com dez sujeitos independentes, sete mulheres e três homens, que adotaram criança a partir de dois anos e meio. As entrevistas foram baseadas em um roteiro previamente delineado (Anexo C). Para analisar os dados, foi utilizado o método de análise de conteúdo (BARDIN, 2011). Das falas dos sujeitos emergiram sete categorias de análise: bagagem da criança; pedras no caminho da adoção tardia; adoção mútua; vivência da parentalidade; motivação para adoção; fantasias e expectativas; participação da rede. A discussão dos resultados da pesquisa foi apresentada em dois artigos, intitulados "Pedras no caminho da adoção tardia: desafios para o vínculo parento-filial" e "Ser mãe, ser pai na adoção tardia: construção do vínculo parento-filial". No primeiro artigo, foram abordadas as principais dificuldades identificadas pelos pais entrevistados, além da repercussão do histórico trazido pela criança, num processo mútuo, tendo sido discutidas as seguintes categorias: bagagem da criança; pedras no caminho da adoção tardia; adoção mútua. No segundo artigo, foram discutidas as experiências subjetivas dos pais, com base no material das seguintes categorias: vivência da parentalidade; motivação para adoção; fantasias e expectativas; participação da rede. 


\section{2.}

\section{Pedras no caminho da adoção tardia: desafios para o vínculo parento-filial na percepção dos pais}

\section{Resumo}

O presente artigo é parte de pesquisa mais ampla sobre o vínculo parento-filial nas adoções tardias. Foram entrevistados 10 sujeitos independentes, 3 homens e 7 mulheres, que adotaram crianças maiores de dois anos e as entrevistas analisadas pelo método de análise de conteúdo. O objetivo deste estudo foi investigar a vivência do período de adaptação nas adoções tardias e a repercussão do histórico pregresso da criança na construção do vínculo parento-filial. Dentre as principais dificuldades relatadas durante esse período, ressaltam-se o comportamento agressivo da criança, as dificuldades com regras e autoridade, a falta de segurança jurídica, o atraso escolar e problemas quanto à adaptação à rotina familiar, todas relacionadas às vivências passadas para a criança. A forma como os pais acolheram as dificuldades, integrando passado e presente, de modo a reconstruir o ambiente familiar perdido, foi relatada como de extrema importância para a construção e manutenção do vínculo parento-filial.

Palavras-chave: Adoção tardia; vínculo; parentalidade.

\section{Abstract}

The present article is part of a broader research on the parent-child bond in late adoption. The authors interviewed ten independent subjects - three men and seven women, who adopted children older than two years - and assessed the results using the content analysis method. The purpose of this study was to investigate the experience of the adaptation period in late adoption, and the repercussions of the previous child history the construction of the parent-child bond. Among the main challenges reported during this period, the authors highlight the aggressive behavior of the child; trouble dealing with rules and authority; lack of legal security; school delays; and problems adapting to family routine, all of which seem to be related to the previous experiences of the child. The way in which 
parents embraced hardships, bridging past and present in order to rebuild the lost family environment, was reported as having critical importance in the construction and maintenance of the parent-child bond.

Keywords: Late adoption; parente-child bond; Difficulties; adaptation period; History of the child

No Brasil, muitas crianças e adolescentes passam parte de suas vidas em instituição de acolhimento. Algumas delas aguardam a reinserção no seio familiar de origem, enquanto outras compõem a lista para adoção. De acordo com o Estatuto da Criança e do Adolescente (ECA), o tempo de acolhimento de uma criança em instituição deve ser transitório, priorizando o convívio familiar (BRASIL, 1990). Em 2009, após 19 anos, o ECA sofreu sua primeira reforma. A Lei Nacional de Adoção (BRASIL, 2009) alterou 54 artigos da primeira Lei, além de promover algumas inovações.

De acordo com essa lei, as instituições de acolhimento ficam responsáveis por adotarem o princípio da preservação dos vínculos familiares e da promoção da reintegração familiar. Desta forma, nota-se que a nova lei tem como principal prerrogativa auxiliar as famílias visando promover o restabelecimento do convívio familiar o mais breve possível (SILVA \& ARPINI, 2013). Contudo, essa ainda é uma realidade que não foi alcançada. As crianças permanecem por muito tempo nos abrigos, tornando a possibilidade de adoção cada vez mais difícil.

Em muitos casos, devido à demora na tentativa de reinserção familiar, o processo de destituição do poder familiar da família de origem se faz muito longo e, por isso, a criança fica disponível para adoção já com a idade mais avançada. Diante desse quadro, a maioria das crianças que compõem a lista de espera são maiores de dois anos, configurando as chamadas "adoções tardias" (VARGAS, 2013).

Apesar de não haver distinções entre as formas de adoção no âmbito jurídico, existe a separação de tipos de adoção, já que algumas requerem atenção especial por serem consideradas especialmente difíceis. Dentre estas, encontramse as adoções de grupos de irmãos, de crianças HIV positivo, adoções interraciais, de crianças com necessidades especiais e a adoção tardia (PEITER, 2011). No caso das adoções tardias, a própria nomeação particular aponta para existência de singularidades e especificidades, dentre as quais, o histórico de vivências 
anteriores, as dificuldades no período de adaptação e a prerrogativa de escolha da criança.

Segundo Ebrahim (2001), o perfil das crianças maiores, geralmente, não se enquadra na preferência da maioria dos pretendentes à adoção. Por isso, acaba sendo a opção, na maioria dos casos, de casais que já passaram pela experiência parental, de solteiros, de indivíduos divorciados e viúvos que não possuem disponibilidade ou desejo de cuidar de um recém-nascido. Frequentemente, a justificativa para preferência por bebês aparece relacionada com a dificuldade na educação de uma criança maior e com a busca por melhor adaptação entre pais e filhos sem interferência de aprendizados anteriores. Trata-se de uma tentativa de amenizar as consequências de vivências que a criança possa trazer consigo, satisfazendo, assim, o anseio da família de reproduzir um modelo biológico (MORELLI, SCORSOLINI-COMIN; SANTEIRO, 2015).

Weber (1996) realizou uma das principais pesquisas sobre adoção na sociedade brasileira. Os dados da pesquisa revelaram o perfil dos pais adotivos como sendo: $91 \%$ casados, faixa etária em torno dos 40 anos, 55\% não possuem filhos biológicos e a maior parte pertence a classes com boas condições financeiras. Na mesma pesquisa, a autora traçou o perfil das crianças adotáveis e não adotáveis. A preferência de $76 \%$ se deu por crianças saudáveis, $69 \%$ preferem bebês até 3 meses, 60\% da escolha se deu por meninas e 64\% de preferência por pele clara. Obviamente, esse perfil não corresponde às crianças acolhidas à espera de adoção.

A consequência da distorção entre preferência e perfil disponível aparece na disparidade dos números estatísticos contidos em relatórios do Cadastro Nacional de Adoção (CNA). No ano de 2016, são 35770 pretendentes disponíveis aguardando pela chegada de um filho, enquanto existem 4943 crianças e adolescentes disponíveis para adoção (CNA, 2016).

Nos últimos 20 anos, muitos avanços foram alcançados por meio da conscientização dos pretendentes sobre o perfil da criança, sobretudo devido ao trabalho realizado nos Grupos de Apoio à Adoção, organizações sem fins lucrativos, coordenadas, comumente, por pais adotivos, militantes do movimento a favor de uma nova cultura da adoção. Amim \& Menandro (2007) destacam que o trabalho realizado nesses grupos auxilia na mudança do perfil escolhido inicialmente durante o cadastro. Segundo os autores, apenas $4 \%$ dos pretendentes 
chegam ao grupo dispostos a adotarem crianças maiores de quatro anos e, ao final dos encontros, esse número já chega a $20 \%$.

Apesar das transformações ocorridas até aqui, construir uma nova cultura da adoção no Brasil que quebre antigos mitos e preconceitos é uma tarefa que ainda impõe muitos desafios. A adoção se apresenta como principal solução para tentar reconstruir um ambiente familiar que se adeque às necessidades da criança com um histórico de perdas e separações. A literatura tem mostrado que o processo de adoção tardia envolve diversas especificidades e desafios tanto para os pais quanto para as crianças, sobretudo, no que diz respeito ao período inicial de convivência (GHIRARDI, 2009; LEVINZON, 2000; LEVY, PINHO, FARIA, 2009; PEITER, 20011).

Ghirardi (2009) aborda o tema da devolução nas adoções tardia. Sem dúvida, existem casos em que a adoção é bem sucedida para ambas as partes. Todavia, por se tratar de um processo que remete a vivências de desamparo e abandono, a devolução encontra seu cenário marcado. A realidade da devolução é encontrada em alguns casos em que os pais devolvem a criança à instituição de abrigo a partir da intensificação dos conflitos na relação e das dificuldades de sustentar o projeto da adoção. Geralmente ocorre no período da tentativa de estabelecimento do vínculo parento-filial no chamado "estágio de convivência".

Os casos de "adoção à brasileira", termo utilizado para designar as adoções que não são tramitadas juridicamente, a dificuldade de legalizar a situação da adoção já aponta para uma dificuldade da construção da parentalidade (LEVY et al., 2009). Quando a criança é integrada à família como filho, as dificuldades que se sucederão serão encaradas como as vividas em famílias biológicas. Para Levinzon (2000), maus pais adotivos, provavelmente, seriam também maus pais biológicos. Se os pais adotivos experienciarem a adoção como algo perturbador, a relação pode se apresentar turbulenta. Desta forma, assim como acontece na parentalidade natural, os filhos adotivos não terão problemas se os pais não tiverem.

O histórico de convivências complexas com a família de origem, vizinhos ou conhecidos, além da passagem por instituições de acolhimento são as principais especificidades da adoção tardia (PEITER, 2011). Assim, pode-se dizer que a construção do vínculo parento-filial será permeada pelas vivências anteriores, tanto dos pais quanto das crianças, num processo que demanda 
construção de ambas as partes, considerando que a criança, muitas vezes, já é capaz de discernir o que deseja e compreender a adoção.

O rompimento de vínculos familiares em tempo precoce pode deixar marcas para o desenvolvimento da criança. A ida para família adotiva aparece como um momento de ressignificação de experiências de separações anteriores. Além disso, de acordo com Londen, Juffer e Ijzendoorn (2007), a adoção representa papel importante para o desenvolvimento e pode impedir atrasos no desenvolvimento cognitivo e motor da criança.

A adoção pode ser entendida como a possibilidade de reinvestir em objetos que outrora foram ameaçados devido a experiências de ruptura de vínculo. Todavia, é importante destacar que a adoção não pode ser vivida como uma solução mágica para todos os problemas. Peiter (2011) salienta que essa não é uma alternativa que, por si só, seja capaz de ultrapassar os traumas que possam haver na trajetória dessas crianças.

As vivências anteriores podem ter deixado marcas e traumas que influenciariam as vinculações futuras. Para Winnicott (1945), as experiências vividas como trauma, inicialmente, são experienciadas no corpo, não tendo representação psíquica. Essas e outras experiências vão se acumulando no histórico dessas crianças desde o rompimento com a família biológica, incluindo a passagem por instituições de acolhimento, até a chegada na família adotiva. Compreender esse percurso pode ajudar os pais a lidarem com as possíveis dificuldades que se apresentarão durante a adaptação (MMORELLI et al., 2015; SCHETTINI, AMAZONAS \& DIAS, 2006; SILVA, GUIMARÃES \& PEREIRA, 2014).

De acordo com a teorização de Winnicott, a mãe que consegue se adaptar às necessidades do bebê, se antecipando e compreendendo os diferentes tipos de demanda, denomina-se mãe suficientemente boa, capaz de oferece facilitação para que o bebê constitua seu self, sobretudo funcionando como ego auxiliar. O bebê irá se constituir como pessoa a partir dos cuidados primordiais e da relação com a mãe ou cuidador(a) principal. Na medida em que a mãe acolhe as necessidades do bebê, ele vivencia a integração das funções corporais, permitindo o estabelecimento de uma unidade. Assim, o bebê poderá constituir seu self de forma satisfatória e experienciar a continuidade do ser. 
Para explicar esse estado de atenção às necessidades do bebê, Winnicott (1956) lançou mão do conceito de preocupação materna primária, que se caracteriza pela sensibilização exacerbada iniciada no final da gravidez e que se estende até algumas semanas após o nascimento. A saúde psicológica e física do bebê dependem da capacidade da mãe de entrar nesse estado e é a partir dele que a mãe se tornará capaz de atender às necessidades do seu filho.

Ochoa-Torres \& Lelong (2006) destacam que os pais que possuem essa sensibilização adequada serão capazes de compreender as situações de acordo com a perspectiva do filho, se antecipam aos sinais do bebê, interpretando-os corretamente e respondendo de forma rápida e satisfatória. Importante destacar que essa mãe ambiente não necessariamente é aquela que gesta a criança. Tal identificação vale tanto para mãe biológica quanto para o(a) cuidador(a) principal, podendo ser pai e/ou mãe adotivos.

A maternidade e o conhecido "amor materno" não são sentimentos inerentes à condição da mulher, ou seja, não é determinado à priori, mas algo construído (MIRANDA \& COHEN, 2012). Sendo assim, o cuidador principal pode ocupar esse lugar de ambiente suficientemente bom, sendo capaz de satisfazer as necessidades da criança e se constituir como pai e/ou mãe.

$\mathrm{Na}$ adoção, é importante que haja identificação e sensibilização em relação à criança para que suas necessidades possam ser atendidas, sobretudo se tratando de adoção de crianças maiores, na qual possivelmente esse primeiro momento de cuidado e atenção às necessidades se mostrou falho ou inexistente. Assim, a mãe/pai adotivos também poderão entrar no estado de preocupação materna primária, oferecendo o cuidado necessário para que essa criança se desenvolva e se sinta segura num ambiente capaz de proporcionar o que um dia possivelmente se perdeu ou faltou (GOMES, 2006).

A chegada numa família adotiva será perpassada pelas histórias, marcas e possíveis traumas experienciados pela criança que, muitas vezes, é exposta a situações de risco registradas no aparelho psíquico como, por exemplo, descuido e desapego, e isto pode gerar dificuldades em criar novos vínculos (ZORNIG \& LEVY, 2006). Nesse contexto, ao abordar o tema de adoção de crianças maiores, a reflexão sobre o histórico e experiências anteriores à adoção se mostra fundamental para compreender a construção do novo vínculo parento-filial. Portanto, é na demanda de reconstruir um ambiente suficientemente bom, além da 
busca por satisfazer as próprias motivações para uma adoção, que as famílias adotantes encontrarão desafios importantes na construção do vínculo (GOMES, 2006; OTUKA, SCORSOLINI-COMIN \& SANTOS, 2012).

Diversas pesquisas apontam para a importância de legitimar o passado da criança, dando espaço para que o histórico possa ser recontado e não ocupe o espaço de fantasma na relação familiar (EBRAHIM, 2001; LADVOCAT, 2001; LEVINZON, 2004; SILVA et al., 2014; SCHETTINI et al., 2006; ZORNIG \& LEVY, 2006). LADVOCAT (2001), ao falar sobre os mitos que envolvem as famílias adotivas, destaca que o desconhecimento acerca da história das origens da criança, na maioria dos casos, acaba favorecendo o surgimento de mitos difundidos pela cultura. Alguns pais preferem apagar a vida anterior do seu filho na tentativa de construir uma nova, sobretudo pela busca de reprodução do modelo biológico de família. Contudo, o acesso ao passado se faz fundamental para que a criança possa fantasiar, perguntar e elaborar junto à família adotiva sua história. É necessário que os pais adotivos compreendam que "ser pai/mãe" é mais importante do que gerar um filho.

De acordo com Schettini et al. (2006), o histórico da criança adotada representa parte da sua identidade e não pode ser anulado, antes, deve ser integrado à nova ligação afetiva. Ressignificar o passado fará parte do processo de construção da identidade da criança. Para os autores, o que se entende por revelação da história perde sentido na medida em que não existe revelação, mas uma história que é vivida e construída no dia a dia. Diante desse contexto, este estudo teve por objetivo investigar a vivência do período de adaptação nas adoções tardias e a repercussão do histórico pregresso da criança na construção do vínculo parento-filial.

\section{1}

\section{Método}

\section{Participantes}

Foram entrevistados 10 sujeitos independentes, 3 homens e 7 mulheres, pertencentes a 3 famílias monoparentais, 3 homoparentais e 4 heteroparentais, com escolaridade superior, que estão com guarda provisória ou com processo de 
adoção concluído. No caso dos pais com guarda provisória, a destituição do poder familiar pode, ou não, ter sido concluída, embora as crianças estejam em processo adoção. Esse tipo de situação ocorre, frequentemente, no estado do Rio de Janeiro. As crianças foram acolhidas pelas famílias com idades que variaram entre dois anos e seis meses e 11 anos, configurando a chamada adoção tardia, anterior ao período da adolescência. Além disso, o processo de adoção, com a guarda provisória, teve início há, no mínimo, seis meses, antes da realização da pesquisa. (Anexo A)

Instrumento

Uma Ficha Biográfica (Anexo B) foi elaborada de maneira a obter dados gerais sobre, os participantes, a configuração familiar e a adoção. Após o preenchimento da Ficha Biográfica pelo entrevistador, foi realizada uma entrevista individual com roteiro semiestruturado (Anexo C), contendo questões abertas, compostas pelos seguintes eixos temáticos: motivação para a adoção; vivências anteriores, familiares e rede; experiências subjetivas da parentalidade, experiência da construção do vínculo, fantasias relacionadas ao filho imaginado.

\section{Procedimentos}

Após aprovação do projeto de pesquisa pelo Comitê de Ética em Pesquisa da universidade onde foi desenvolvido, os participantes foram recrutados a partir do contato com os Grupos de apoio à Adoção e, também, por contatos informais em diferentes redes sociais da pesquisadora. As entrevistas foram realizadas em local de preferência do entrevistado, gravadas em áudio, com a devida autorização dos participantes, mediante a assinatura de um Termo de Consentimento Livre e Esclarecido (Anexo D), e tiveram duração média de uma hora. Os nomes dos pais utilizados ao longo do trabalho foram devidamente substituídos por nomes fictícios.

O material foi transcrito e submetido ao método de análise de conteúdo, na sua vertente categorial, com a finalidade de investigar, a partir do material discursivo, as significações atribuídas pelas entrevistadas aos fenômenos (BARDIN, 2011). Por meio da técnica categorial, foram destacadas categorias temáticas, organizadas a partir da semelhança entre os elementos contidos no material coletado. Para tal, procedeu-se a uma "leitura flutuante", agrupando-se 
dados significativos, identificando-os e relacionando-os, até se destacarem as categorias de análise.

O presente trabalho apresenta parte dos resultados de pesquisa ampla, cujo objetivo foi investigar a construção do vínculo parento-filial nas adoções tardias. Nessa pesquisa mais ampla, emergiram sete categorias das narrativas dos participantes: vivência da parentalidade, motivação para adoção, participação da rede, fantasias e expectativas na adoção tardia, bagagem da criança, pedras no caminho da adoção tardia e adoção mútua.

Para alcançar os objetivos deste trabalho, foram discutidas as três últimas categorias, por estarem diretamente relacionadas às implicações do histórico na construção mútua do vínculo parento-filial da adoção. As outras categorias foram discutidas em outro trabalho.

\section{2}

\section{Resultados e discussão}

\section{Bagagem da criança}

Os entrevistados relataram receio diante dos costumes e aprendizados adquiridos no passado da criança, sendo essa uma das principais dificuldades iniciais na construção do vínculo parento-filial.

\footnotetext{
"Digamos, ela chegou com onze anos, já chegou com uma bagagem. Como que a gente vai desconstruir, explicar isso pra ela? Às vezes até repreendê-la, mas sem fazer com que ela retorne lá atrás pra falar 'ah! Mas antes isso comigo não acontecia'." (Mario)
}

\footnotetext{
"Algumas coisas ela não deixou e aquilo irritava muito a gente, que era hábitos de morro, né. Funk, um palavrão ou outro, um jeito de pensar ainda de morro, de pobre, né, parece um ranço". (Laura)
}

Segundo Vargas (2013), apesar de a educação ser tão importante quanto a natureza biológica, o temor da herança patológica é um assunto frequentemente abordado por pais adotivos. Assim, prevalece a ideia de que, não importa o que se faça, a personalidade da criança sempre será modelada pela "semente ruim" proveniente do biológico. Luz, Gelani \& Amaral (2014) apontam para a 
importância dessa desmistificação, uma vez que a crença de que a criança virá com maus hábitos pode comprometer tanto a construção do vínculo quanto o próprio desenvolvimento futuro da criança.

Para a grande maioria dos entrevistados, os medos a respeito do que a criança traz consigo foram sendo desconstruídos durante o processo da adoção.

\begin{abstract}
"Quando a gente entrou no processo de adoção, a gente tinha colocado de zero a seis anos, um só, mas eu descobri que esse perfil não era muito baseado em desejo. Ele era baseado em medo e em um bando de fantasias. Então conforme a gente foi fazendo as palestras e eu fui conversando com as pessoas, eu fui ficando mais seguro com relação a isso". (Lucas)
\end{abstract}

Nas falas de alguns pais, pode-se notar o receio de que o preconceito e os estigmas provenientes da educação recebida prejudicassem o vínculo parentofilial. Para Mario, a aceitação ou não da homossexualidade foi uma das preocupações ao decidir adotar.

\begin{abstract}
"Uma das coisas que nos preocupava era a bagagem que a criança trazia. (...) E outra grande preocupação era a questão do gênero, no início a gente ficou meio assim porque achava que como era um casal gay, a facilidade seria menina, né. Porque a menina lidaria muito melhor com a questão nossa da homossexualidade e o menino já carregaria aquela bagagem preconceituosa do local de onde veio, que geralmente são lugares mais carentes, mais pobres, e como isso seria?" (Mario)
\end{abstract}

Segundo Fernández \& Fuentes (2004), nos países ocidentais, tratando-se de adoção de crianças maiores, nota-se preferência pela adoção de meninas. Isso se deve a aspectos psicológicos da escolha, como, por exemplo, a busca de afeto e apoio, além de aspectos sociais e culturais, como a valorização da atração estética, da obediência e da submissão atribuídas ao gênero feminino.

A dificuldade com os cuidados básicos de higiene apareceu nas falas de alguns dos entrevistados como uma das dificuldades relacionadas ao histórico marcado por negligências.

"Então a gente tem que iniciar uma nova educação, literalmente. Apesar deles terem dez e quatro era como se fossem bebês. Escovar dentes, tomar banho todos os dias, então, coisa de histórico, escovar dente, tomar banho (...) Teve uma reeducação total praticamente devido ao histórico deles que era um histórico de crianças largadas.” (Fernanda) 
"Eles não sabiam jogar o lixo na lixeira, eles não sabiam se limpar, eles não sabiam tomar banho, não sabiam escovar dente, não sabiam nada, nada. A negligência deles era demais." (Claudia)

A rotina nos abrigos, muitas vezes, não favorece o aprendizado de cuidados essenciais. A predominância da função assistencialista, somada à falta de estrutura dos abrigos, fragiliza o compromisso voltado ao desenvolvimento da infância e da adolescência. Essas instituições não conseguem abarcar toda a demanda de cuidados necessários às crianças devido a inúmeros fatores como, por exemplo, número reduzido de funcionários, alta rotatividade, sobrecarga de funções, salários desfavoráveis e falta de especialização (ALTOÉ \& SILVA, 2013)

Baptista, Soares \& Henriques (2013) destacam que a impossibilidade de oferecer a satisfação dos cuidados básicos nas instituições está relacionada à baixa capacidade em alcançar as necessidades individuais das crianças. $\mathrm{O}$ reduzido número de cuidadores e as mudanças constantes nos turnos impossibilitam a existência de certa estabilidade desses profissionais e desfavorecem a promoção de atividades para o desenvolvimento dessas crianças. Esses fatores acabam prejudicando o estabelecimento de figuras de referência, podendo fragilizar a capacidade de vinculação futura com a família adotiva.

Toda essa negligência sofrida no passado pode ter consequências importantes para o desenvolvimento. Alguns pais destacaram defasagens no desenvolvimento como parte do histórico dos seus filhos.

"Ela vivia presa em algum lugar, porque ela com um ano e meio, ela não andava, ela não engatinhava, ela não falava (...) Então com dois meses ela já tava correndo. Aí o pessoal do abrigo falava assim: 'ela não anda, só corre'. Aí você, é claro, né! Perdeu muito tempo sem fazer nada, tem que botar o tempo em dia". (Julia)

"Ela não trouxe nenhuma coisa ruim do passado dela. (...) O passado dela afetou mais a questão cognitiva, afetou muito". (Claudia)

Bôing \& Crepaldi (2004) assinalam que observações em hospitais, creches, abrigos nos quais a privação, por vezes, é maciça, mostram que os danos no desenvolvimento psicoafetivo aparecem de forma grave, no que seria denominado de "hospitalismo". Além disso, quando a privação é severa, pode ocorrer o dificuldade da capacidade da criança de estabelecer vínculos futuros. 
A defasagem advinda da falta de cuidados iniciais, emergiu nas falas dos entrevistados sobre a dificuldade com a adaptação da rotina familiar.

"E aí quando eu cheguei no mercado falei com o T assim, toda feliz, né, achando que eu tava abafando: e aí, qual iogurte que você gosta? Aí ele olhou pra mim e falou assim: 'o que é iogurte mesmo'? Aí que eu comecei a perceber das dificuldades. Aí aqui em casa quando ele olhou o ar condicionado, ele olhou e perguntou o que era aquilo, então o choque de realidades foi muito grande". (Sara)

"A dificuldade foi essa parte da adoção mesmo porque eles reagiram de uma forma que cada um reage de uma forma, que nem a da B que chorava muito, né, o L que falava só sim, então a dificuldade foi tentar entrar no meio termo, colocálos num ponto, alinhá-los de acordo com a rotina da família”. (Fernanda)

A necessidade de cuidados para reparar o que antes foi negligenciado requer transformações de rotinas. Conforme Luz et al. (2014), a rotina se apresenta como questão importante na adaptação, tanto para a família que irá receber um novo membro, quanto para a criança que, por conta do seu histórico, pode não aceitar tão bem a imposição de novas regras.

A falta de informação sobre o histórico da criança também foi mencionada, sobretudo na fala de Sara, ao contar sobre seu desespero ao se deparar com o filho doente.

"E eu não sabia nada, nada, nada, nada. Eu falei, olha doutora, eu só sei o tipo sanguíneo dele porque me deram no abrigo, o resto eu não sei nada, nada, não sei histórico dele nenhum, a senhora, por favor, me ajuda que essa criança fica com secreção o tempo todo e eu não sei o que eu faço". (Sara)

Gomes (2008) assinala que, na maioria das vezes, a família adotiva não têm acesso a informações essenciais sobre o início de vida da criança como as condições do parto, histórico de doenças comuns na infância, aspectos relevantes do avanço no desenvolvimento, dentre outros. Diante disso, terá que oferecer cuidados específicos à adoção para conseguir reparar as falhas anteriores.

A insegurança da criança foi reconhecida por alguns entrevistados como uma das consequências da história pregressa dos seus filhos. Perceber isto ajudou a moldar o cuidado necessário para que a segurança fosse reestabelecida.

"Ela veio de uma experiência muito ruim com a adoção, ela foi devolvida três vezes (...). " Então a gente pegou uma criança com alta desconfiança, não confia 
mais num adulto e no ser humano, isso é horrível, é uma dor muito grande pra criança, é uma ferida". (Vânia)

"Nossa primeira, vamos dizer assim, não foi briga, nossa primeira bronca mais séria, né, com a minha cara mais séria, ela na hora disse assim: "você vai me abandonar?' (...) Eu nunca falei quando ela fazia alguma pirraça na rua, igual mãe faz, assim: não vai vir não? Então vou embora! Nunca falei isso, podia tá o que fosse. (...) Mas na rua, falar: oh, to indo embora e você vai ficar aí, nunca falei, porque vai trazer um sofrimento que já é, na verdade, pra qualquer criança, né, a mãe falar que vai embora, pra qualquer criança já é um sofrimento. Mas pra elas é maior ainda, porque já foram né, outros já foram e nunca mais voltaram”. (Julia)

Ao longo de suas histórias, as crianças adotadas passaram por vivências de rupturas desde a família de origem. Desta forma, carregam consigo muita insegurança diante do outro, que pode desaparecer a qualquer momento. Para Silva et al. (2014), estas experiências fazem com que a criança empregue esforço psíquico demasiadamente grande na construção de novos vínculos. Trocar o abrigo, ambiente já conhecido, pela nova família, ambiente totalmente desconhecido, traz insegurança, uma vez que, na sua imaginação, a família pode ser um lugar perigoso.

Embora a maior parte das vivências anteriores das crianças tenha sido reconhecida pelos participantes como algo que trouxe consequências ruins para o presente, os entrevistados destacaram também a importância do passado na formação, demonstrando atenção aos aspectos bons de seus filhos e a importância de falar sobre o assunto.

\footnotetext{
"Uma coisa muito boa do passado dessas crianças é que eles têm um senso de família fora de série. Não sei se eles tinham que se juntar pra se proteger, eles são muito... eles ensinam pra gente muito a união familiar". (Claudia)

"Tem o lado que você tem que quebrar alguns conceitos, algumas histórias que nem sempre são boas, né, não trazem coisas boas, mas também procurar coisas boas nas histórias do passado que todos eles têm também, né. Porque pra chegar aonde chegaram e serem crianças como são é porque eles têm grandes valores aí, né.” (Mario)

"Então essas experiências, elas chocam... Não vou dizer que chocam não, elas complementam o nosso convívio que aí eu consigo entender algumas coisas, algumas demandas delas, consigo, dali, gerir o que eu vou fazer. (...) Olha, não proíba o seu filho de falar do passado que é pra você entender o que aconteceu com ele e trabalhar isso no futuro com ele. (...) Então essas experiências anteriores delas serve até pra entender a dinâmica delas hoje". (Vânia)
} 
Na medida em que os pais compreendem as experiências trazidas, pode-se construir uma nova história que elabore o que do passado possa ter sido vivido como traumático e doloroso. Conforme assinalado por Silva et al. (2014), ouvir o passado possibilita que a criança reconte sua história e possa dar novos significados para ela. Ademais, de acordo com Schettini et al. (2006), a história da criança poderá dizer muito mais sobre a identidade que o filho adotivo irá assumir do que desse suposto passado.

A maioria destas crianças possui apegos e memórias importantes de convivência com a família biológica que, muitas vezes, são preservadas. A família adotiva terá que lidar com essas vivências. Diante disso, a família adotiva, ao receber seu filho, recebe também toda história vinda na bagagem. Os desafios de lidar com esse passado e escrever uma nova história se relacionam com as dificuldades nesse caminho de construção.

\section{Pedras no caminho da adoção tardia}

As pedras no caminho da adoção tardia representam as principais dificuldades que os pais adotivos enfrentam no período inicial do convívio. Dentre estas, os entrevistados destacaram o comportamento agressivo com o qual tiveram que lidar no período de adaptação. Na adoção, muitas vezes, a família adotante idealiza que a criança será grata ao acolhimento e não causará maiores "problemas". Ao contrário, ela irá testar o ambiente de forma a obter a certeza de que será aceita mesmo com tudo de provocador e insatisfatório que possa ter (LEVINZON, 2000), como evidenciado na fala de Fernanda:

\footnotetext{
"As fases. Bem que me avisaram! Quando as crianças chegaram não foi um conto de fadas, isso é importante falar. Porque a gente acha que a criança vai tá muito grata, como muitas vezes acontece, mas nem sempre é assim. (...) A B quando ela chegou ela testava muito. Ela tinha choros e birras... O vento mudou de posição, ela já estava chorando e eu achei que alguém ia bater na minha porta me acusando de maus tratos porque ela gritava, gritava... B, por que você tá gritando? 'Não sei!'” (Fernanda)
}

De acordo com Weber (1996), o comportamento agressivo do filho adotado diz respeito ao medo da criança de ter a experiência de abandono repetida. Assim, ao invés de demonstrar amor, ela começa a testar esse novo ambiente e a demonstrar seu ódio. Para Winnicott (1947), muitas vezes, o que a 
criança procura é um ódio legítimo, e deve poder encontrá-lo, ao contrário, se sentirá incapaz de alcançar o amor. Nesta perspectiva, o autor menciona que as crianças vindas de lares desfeitos vivem em busca, mesmo que inconscientemente, dos pais. Essa testagem faz parte do processo de vinculação e se configura como algo estruturante no processo de filiação e não deve ser entendido como algo destrutivo. A fala de Vânia exemplifica esse momento

\begin{abstract}
"O ruim da adoção tardia é justamente isso, você não consegue nutrir, você não consegue trabalhar amor com a criança, então tem que ter não é amor, é paciência, a chave pra adoção tardia, eu falo, é paciência, porque a criança não vai vim pra você 'Mamãe eu te amo!' 'Mamãe você é linda!' 'Mamãe muito obrigada!' não vai, ela vai te infernizar, ela vai bagunçar a sua estrutura emocional toda." (Vânia)
\end{abstract}

Para Levinzon (2000), o abandono por parte dos progenitores, muitas vezes, está ligado à fantasia de morte para a criança, o que acaba gerando um mundo interno repleto de fantasias de destruição.

"Um período que ele teve, assim, muitos episódios de agressividade, né, que o K, meu marido, às vezes ele tentava conter, às vezes, e ele dava mordidas, chutes, eu fiquei toda roxa também, porque no trato ele batia. (...)Mas era em algumas situações e assim, ele mesmo não se dava conta do que tava fazendo. Tanto que quando ele percebia que machucava, ele parava" (Ana)

"O mais novo nós tivemos um problema que ele tinha explosões de raiva, então a gente tinha que conter ele e sempre que a gente colocava limite ele explodia. A gente teve que conter porque ele estava completamente violento, xingava todos os nomes que você possa imaginar gritando e dizendo que ia matar a gente que queria matar a gente, que queria voltar pro abrigo." (Lucas)

"E desde o momento que ela foi pra minha casa foi um tumulto muito grande porque ela era totalmente desequilibrada, muito desequilibrada em todos os sentidos, sabe? Falava muito palavrão, era... sei lá, os hábitos dela, o jeito dela era muito confrontativa". (Laura)

Conforme ilustrado nos relatos, a criança irá colocar para fora toda sua raiva em direção aos pais adotivos. Essa raiva deve ser acolhida e contida, demonstrando que eles podem sobreviver aos ataques. A criança precisará retomar a confiança no ambiente e reviver o que Winnicott (1963) chamou de ciclo benigno, formado a partir das repetidas vezes em que o bebê se percebe atacando de maneira voraz o corpo materno e experimenta o sentimento de culpa, não consciente, pelas consequências de sua agressividade destrutiva. A partir disso, 
ele vai em busca de reparação, que deve ser acolhida pela mãe. Quando a mãe é capaz de acolher, por repetidas vezes, a destrutividade e o ato reparatório, num processo cíclico, o bebê se torna capaz de seguir sua construtividade, apropriandose dos impulsos destrutivos de forma produtiva à vida.

O ciclo benigno deve ser retomado na adoção e os pais adotivos devem ser capazes de oferecer à criança a possibilidade de se apropriar de sua agressividade de forma construtiva. Essa vivência foi descrita por Vânia, ao contar como se deu a testagem do ambiente e a resolução desse movimento agressivo:

"Com a $\mathrm{R}$ foi tenso, porque ela não confiava na gente, então ela praticou tudo que ela podia fazer pra ser devolvida né, então foi... Foram seis meses de inferno, quando eu falo inferno, é inferno no último nível (...) Aí nesse dia eu tava dando banho nela, ela saiu correndo do banheiro e veio pra sala, toda molhada, com shampoo, gritando aqui, aí a Paula (esposa) levantou, pegou ela. Nesse dia, até esse dia, a Paula não tinha feito nada, deixou a $\mathrm{R}$ fazer de um tudo. Aí ela segurou ela pelos braços, puxou, trouxe até o rosto dela e falou 'Presta atenção, você pode botar fogo na casa...' aí foi falando o que ela podia fazer e o que ela não podia, 'E você não vai ser devolvida, essa aqui é sua casa, sua família, aceita que dói menos'. Soltou, nisso que ela soltou a menina, a menina parou, olhou pra mim, 'Mãe, vamos lavar o cabelo?’”. (Vânia)

Outra dificuldade apontada pelos participantes foi a falta de segurança jurídica. Muitos dos processos de adoção que correm em juízo, atualmente, não contam com a destituição do poder familiar e isso apareceu nas falas da maioria dos entrevistados. Uma das prerrogativas do ECA é a restituição do convívio familiar, por isso, o processo de destituição familiar, muitas vezes, demora a ser concluído, até que se comprove que a família de origem não é capaz de retomar o cuidado da criança. Isso favorece que as crianças sejam postas para adoção com idade mais avançada, configurando a adoção tardia. Além disso, em alguns estados brasileiros, incluindo o Rio de Janeiro, a criança é colocada em família substituta, sob guarda provisória, antes mesmo da conclusão desse processo que acaba transcorrendo paralelamente ao processo de adoção. Isso acaba gerando insegurança para os pais adotivos que apresentam um sentimento de desamparo enorme. Isto terá implicação na formação do vínculo parento-filial.

"Eu acredito que muitos dos problemas de adaptação e de vínculo têm a ver com essa falta de empoderamento que se dá à família substituta, que decorre, na verdade, de uma falta de segurança jurídica." (Ana)

"Aí que eles tiraram as criança. Tiraram e não tiraram, porque ainda tá lá no processo, o pai ainda manda. É incrível, o pai ainda manda! Eu ainda posso 
algum dia receber uma cartinha ou um telefonema dizendo: volta com teus filhos, eles vão morar com os pais. Incrível isso! Que pais? A gente aqui todo relutante numa educação que não traumatize, que dê certo, né. A gente todo preocupado de como fazer, como agir e errando e acertando, mas preocupado sempre. (...) E é um temor que a gente tem muito, muito mesmo. Eu não acho que vai acontecer, mas... até tá lá o nominho na certidão (...) a gente fica com o pé atrás." (Fernanda)

A maioria dos entrevistados mencionou a dificuldade no estabelecimento de regras:

"Dificuldades no caso dele foram assim, ele não tinha, até hoje ele não tem ainda, costume com regras, disciplinas (...)foi essa dificuldade, a dificuldade foi ele acostumar, acho que é normal, ele se reeducar com novas disciplinas, novos horários, o colégio, enfim, com uma nova vida, né gente!" (André)

“A maior dificuldade foi em relação às regras, porque eles estavam acostumados com regras totalmente diferentes (...)E uma teimosia que não chega a ser diferente de uma teimosia de qualquer criança." (Lucas)

Costa \& Rossetti-Ferreira (2007) destacam que a principal dificuldade do pai adotivo em desenvolver sua parentalidade com crianças maiores está na contestação das regras e do seu lugar de autoridade. A criança maior já chega com a capacidade de se contrapor e argumentar junto aos pais, o que reflete uma das particularidades desse tipo de adoção e pode ser notado em algumas falas.

Outra dificuldade mencionada pelos participantes foi a questão do atraso escolar. Na grande maioria dos discursos, emergiu o desafio em lidar com o analfabetismo dos filhos.

"E a outra era a questão da educação mesmo, da educação formal. Ela não sabia separar sílabas e ela tava no quarto ano, na época. Então a gente vai levar ela pra uma escola particular e como é que ela vai ficar?" (Mario)

"A G, ela chegou pra gente, com 12 anos, sem saber ler e sem saber escrever, então nós entramos num processo com ela de acelerá-la, então a gente colocou na escola particular, colocou no Kumon e numa explicadora, pra ela começar a ler e a escrever, porque eu tomei um susto quando eu descobri que uma pessoa de 12 anos, em 2012, né, não é no século da vovó, não sabia ler, não sabia escrever, isso me apavorou." (Vânia)

Outro aspecto mencionado nas falas dos pais foi a ambiguidade entre amadurecimento precoce e regressão infantil. Estas crianças tiveram que assumir um lugar de independência no autocuidado, mesmo que de forma precária, muito cedo (ALTOÉ \& SILVA, 2012). Por isso, observa-se nas crianças que vivem em 
abrigos, de um modo geral, certa pseudo-autonomia. Contudo, ao sentirem-se seguros numa família que ofereça cuidado, nota-se certa regressão, no sentido de assumirem posturas infantis, como forma de permitir o cuidado.

\begin{abstract}
"Agora ela está resgatando uma infância que ela não teve. Então tem umas atitudes super maduras, porque ela foi obrigada a amadurecer, mas ela tem uma atitude super infantil de crianças de dois anos de idade." (Claudia)

"Quando chegou ela era uma criança completamente independente pra uma criança de dois anos e meio, eu só não digo que era cem por cento porque ela ainda usava fralda. (...) Aí depois teve a regressão né, me ajuda, não sei fazer, não sei o que, nada fazia mais sozinha. (...) Quis mamar no meu peito, eu falei assim: mas não sai leite! (risos) nem você tem mais idade pra isso. 'ah, mas eu quero!'. Não adianta, eu deixei, aí falou: 'não sai' aí eu: pois é, não sai. Falei assim, você quer beber seu leite no copinho, na posição? 'ah, quero!' Aí botei ela deitadinha, como se realmente tivesse sendo amamentada, mas no copinho, que nem na mamadeira ela bebia mais.” (Julia)
\end{abstract}

Todas essas dificuldades mencionadas pelos entrevistados foram acolhidas de forma singular, favorecendo a construção do sentimento de segurança e fortalecendo o vínculo na medida em que a criança percebia poder confiar nesse novo ambiente cuidador. Todavia, para uma das mães entrevistadas, lidar com a testagem demasiadamente intensa da filha estava sendo, até o momento da entrevista, um desafio muito complexo, mesmo depois de seis anos da adoção. Nota-se, na sua fala, a fragilização desse vínculo:

"Então o amor pra mim... eu sei lá, algo assim que eu não sei mensurar. Eu só sei que desde o momento que ela entrou na minha vida, ela se tornou minha filha, né. É lógico que assim, o meu amor foi se desgastando (...) Então hoje em dia, eu penso assim, será que o que eu sinto hoje em dia é desamor? Entendeu? Hoje, com essas coisas que eu to vivendo, será que é um desamor? Será que não era nada daquilo e eu achei que fosse? Será que era compaixão? Será? O que será que era, né? Então assim, hoje eu sinto um pesar muito grande. É como se fosse assim, alguém que me deu uma decepção muito grande e assim, que eu queria tirar do meu peito, mas eu não posso tirar do meu peito." (Laura)

\title{
Adoção mútua
}

A ideia de construção mútua foi expressa nas falas dos sujeitos demonstrando como os desejos, vivências e vontades próprias das crianças influenciam diretamente na construção do vínculo parento-filial. 
"Eu acho que encontrei meu filho mesmo. E talvez... eu até te falo, foi até melhor do que se fosse um filho gerado, porque esse eu tive toda chance de, entre aspas, escolher e ele me escolher e a gente tá construindo juntos, uma vida juntos, com desafios, com problemas, mas com muito carinho, com muito amor." (André)

Mas, da mesma forma que a gente quer que a criança se adapte, a criança também quer ser adaptada, né. Então ela também se esforça pra isso, também tem esse viés dela, ela se esforça, ela também quer pertencer a uma família. (Lucas)

$\mathrm{Na}$ adoção tardia, já existe uso da linguagem e uma história pregressa que fazem com que a criança se apresente não mais como um ser incompleto e, por isso, exige outros modos de vinculação afetiva. Segundo Costa \& RossettiFerreira (2007), nessas adoções, as crianças são capazes de negociar a afetividade e a construção do amor filial, posicionando-se na relação de forma mais ativa que um bebê. Tal proposição ficou evidenciada nas falas de Vânia e Claudia:

\begin{abstract}
"Aí ela fez uma pergunta que me marcou, uma criança de 5 anos e 6 meses fazendo esse tipo de pergunta, ela perguntou assim 'É para sempre? Todo sempre?' eu nunca tinha ouvido dessa forma o tal do 'para sempre' junto com 'todo sempre' falei Gente, que pergunta é essa? né, aí aquilo, parei, falei O que que eu respondo?" (Vânia)
\end{abstract}

"Mas o que me emocionou no primeiro momento foi a minha filha porque ela é toda meiguinha, toda sedutora e ela chegou e 'você quer ser minha mãe?' gente! Muito forte uma menina de oito anos falar isso pra você. Aí eu falei: quero! Aí ela começou a me chamar de mamãe, naquele momento." (Claudia)

Alguns dos entrevistados assinalaram a importância de aprender junto com a criança a se tornarem pais:

\footnotetext{
"Porque a gente vai aprendendo a ser pai e mãe com as crianças (...)Eu acho que eles ensinam a gente a ser pai e mãe melhores (...)eles vão me ensinando aos pouquinhos a cuidar deles melhor. (...) De ver que essa troca tá acontecendo. Eu tinha náusea só de pensar em ver um desenho animado, hoje eu já gosto de ver desenho animado. Também eu aprendo com eles." (Claudia)

"Então tá sendo assim, um período de adoção tanto da gente com eles como deles com a gente. A gente também tá aprendendo o que é ser pai (...) Eles mesmos, da mesma forma que a gente localiza eles, olha, do que eles tem que fazer, eles também localizam a gente. (...) Eles, de certa forma, sabem colocar a gente no nosso lugar porque a gente também tem que ser colocado no lugar de pais, né. Da mesma forma que a gente vai colocar eles no lugar de filho." (Fernanda)
} 
A importância da demonstração afetiva emergiu nas falas como formas de reparação do que possa ter sido vivido como ruim no passado e como forma de construção do novo vínculo parento-filial.

\begin{abstract}
"Mas o que que tá fazendo a diferença? Carinho. Você educa com carinho, tem pela outra parte mesmo das sanções que você tem que colocar de castigo, colocar na cadeirinha do pensamento, essas coisas que é igual pra todo mundo, né, independente de ser biológico ou ser adotivo, mas o que faz a diferença é o carinho." (Mario)

"O que me incomoda hoje um pouco ainda, eu acho que tinha que ter uma forma de tirar esse preconceito que existe hoje ainda dessa adoção tardia. Porque eu não vejo como uma criança hoje que se dê carinho, se dê amor, dê apoio, dê um lar, que ela não consiga te devolver de alguma forma isso daí." (André)
\end{abstract}

Alguns pais mencionaram a ilusão inerente à tentativa de "colocar a criança no seu jeito" e a necessidade de respeitar o filho e sua história. Nas falas a seguir, Vânia compara a experiência com $\mathrm{M}$, adotada aos seis meses, com a experiência com as outras duas filhas, adotadas com cinco e com 12 anos. André cita o conflito entre gostos como uma especificidade da adoção tardia:

\begin{abstract}
"Conforme a gente foi vivendo, foi uma aprendendo com a outra. Igual falam assim:" ah, não quero filho grande porque não vou botar do meu jeito." Não existe o meu jeito. Eu descobri isso que não existe o meu jeito. Porque se fosse assim, a $\mathrm{M}$ seria do meu jeito porque ela convive comigo desde que nasceu (...). Então não existe esse botar do meu jeito. Cada um tem o seu jeito, o que a gente aprende é a respeitar o espaço do outro ou podar algumas coisas." (Vânia)

"Essa é a diferença da adoção tardia, porque quando você pega de pequenininho, você doutrina naquilo que você gosta e aos pouquinhos ela vai vendo que ela gosta. Nesse caso não, ele já vem com uma bagagem do que ele gosta, eu preciso respeitar isso (...)Um fato importante e interessante, ele ama filme de terror, ama! E eu odeio filme de terror e proibi ele de ver. Ele ia lá e eu desligava, desligava, desligava. Aí um dia ele falou assim: 'isso não é justo! Quando o senhor me conheceu eu já gostava de filme de terror, então o senhor não quer ver, vai pra o seu quarto e eu vejo na sala. Então eu posso ver, posso?' Então eu parei e falei: ele tá hiper correto, é claro que pode ver!" (André)
\end{abstract}

Nesse processo mútuo, transpassado por vivências e histórias, torna-se inegável que essa bagagem tenha seu efeito na construção do vínculo parentofilial. Conforme assinalado por Schettini et al. (2006), compreender o passado que a criança traz, sem negá-lo, pode favorecer a construção de uma nova história capaz de reparar o que antes possa ter se apresentado como faltoso ou até mesmo negligente. De acordo com Dias, Silva e Fonseca (2008), diante das dificuldades, 
a lucidez, o amor e o empreendimento dos pais no cuidado da criança potencializa a convivência.

\section{3 \\ Considerações finais}

Os resultados da pesquisa apontam para a importância da atenção prestada ao histórico de vivências da criança. Por se tratar de adoção de crianças maiores, elas já irão chegar na nova família com uma bagagem de experiências. Para alguns pais, o medo dos costumes trazidos pela criança, ainda é bastante presente. Contudo, pôde-se perceber, nas falas dos entrevistados, que esses medos eram baseados em crenças anteriores à entrada no processo de adoção. Para a grande maioria, a participação nos Grupos de Apoio à Adoção, as leituras sobre o tema e as palestras com profissionais ajudaram a desmistificar as fantasias sobre as interferências no processo de adoção tardia.

Outro aspecto importante mencionado pelos participantes foi a adaptação à rotina, também associada ao histórico de descuido. De acordo com a fala da maioria dos entrevistados, as negligências sofridas na família de origem e/ou na passagem pelos abrigos que, muitas vezes, não possuem infraestrutura que favoreça o cuidado, colaboraram para a dificuldade na adaptação da rotina familiar.

Ademais, os pais entrevistados apontam para uma lacuna importante no conhecimento das informações essenciais sobre o início do desenvolvimento. Quanto à isso, seria interessante que fossem desenvolvidos projetos que zelassem pelo história de saúde da criança desde o nascimento para que a família adotiva tivesse acesso à informações como, por exemplo, as condições de parto, doenças comuns na infância, avanços no desenvolvimento, e outras.

Dentre as principais dificuldades durante a adaptação, foram mencionadas a imposição de regras, o comportamento agressivo, falta de segurança jurídica, atraso escolar, regressão infantil e adaptação à rotina familiar. Todos esses desafios apareceram para os pais entrevistados e a maneira como cada um acolheu e lidou com cada dificuldade foi de importância fundamental para garantir o fortalecimento do vínculo parento-filial. 
Conhecer o histórico da criança pôde auxiliar as famílias na adaptação quanto às necessidades principais e na ressignificação de possíveis falhas do passado muitas vezes doloroso e marcado por rupturas e abandonos. $\mathrm{O}$ respeito à história pregressa foi essencial para a construção e manutenção do vínculo parento-filial.

Por se tratar de adoção de criança maior, sobretudo, entende-se que essa nova construção se dará como uma via de mão dupla, numa adoção mútua capaz de ressignificar o passado, sem precisar apagá-lo, antes disso, construindo a possibilidade de uma nova história integradora. Desta forma, torna-se possível a construção de um futuro capaz de reparar o que possa ter havido de ruim e legitimar o que possa ter ficado de bom.

O presente estudo foi realizado com um grupo reduzido de participantes, o que não permite a generalização das conclusões aqui apresentadas. Ressalta-se a necessidade de desenvolver pesquisas que abordem fatores que possam interferir na construção do vínculo parento-filial nas adoções tardias, contribuindo com conhecimentos para promoção de saúde emocional das famílias. 


\title{
3.
}

\section{Ser mãe, ser pai na adoção tardia: construção do vínculo parento-filial}

\section{Resumo}

O presente artigo é parte de pesquisa mais ampla sobre o vínculo parento-filial nas adoções tardias. Foram entrevistados 10 sujeitos independentes, 3 homens e 7 mulheres que adotaram crianças maiores de dois anos e as entrevistas analisadas pelo método de análise de conteúdo. O objetivo deste estudo foi investigar como se dá a vivência da parentalidade na adoção tardia, focalizando motivações, expectativas e a importância das redes familiar e social na construção do vínculo parento-filial. As principais motivações relatadas foram o desejo de ser mãe/pai e sentimentos altruístas. Emergiram fantasias de fracasso no exercício da função parental. O suporte da rede se mostrou fundamental para a construção e para a manutenção do vínculo parento-filial.

Palavras-chave: parentalidade adotiva; motivações; expectativas na adoção

\begin{abstract}
The present article is part of a broader research on the parent-child bond in late adoption. The authors interviewed ten independent subjects - three men and seven women, who adopted children older than two years - and assessed the results using the content analysis method. The purpose of this study was to investigate the experience of the adaptation period in late adoption, and the repercussions of the previous history of the child in the construction of the parent-child bond. The main motivations reported were the wish to be mother/father and altruist feelings. They emerged fantasy of failure in the exercise of parental function. The grid support was fundamental for construction and maintenance of the parent-child bond.
\end{abstract}

Keywords: parenting in adoption; motivation; expectation in the adoption. 
Apesar das mudanças importantes que ocorreram na estruturação familiar ao longo dos séculos, a família contemporânea se mantém como base organizadora e importante no que diz respeito à oferta de segurança para seus membros. Isso porque a família se configura como espaço basilar para as trocas afetivas e para a transmissão simbólica.

Ao longo do tempo, a parentalidade vem deixando de ser o objetivo principal na estruturação familiar. A partir disso, Zornig (2010) questiona sobre o que sustenta o desejo de alguém pela parentalidade. A relação de consanguinidade não se mostra suficiente para garantir o exercício parental, tornar-se pai e tornarse mãe tem relação direta com a história individual de cada um, ou seja, a préhistória de cada criança tem início na história individual de cada um dos pais. Por isso, a parentalidade não pode ser restrita à gestação e ao nascimento de um filho, sendo as identificações feitas durante a infância determinantes para o modo como cada um irá exercer sua parentalidade futuramente.

A parentalidade se configura como um conceito relativamente recente. Tem sua origem em 1961, quando Racamier se propõe estudar o conjunto dos processos psicoafetivos que se desenvolvem na mulher durante a maternidade. Para tanto, lançou mão do termo maternalidade. Nesse período, o termo parentalidade já aparece, contudo, não é muito aprofundado, até que ressurge em 1985 com René Clément (HOUZEL, 2006).

A parentalidade quer dizer, em sua essência, que não basta gestar nem se denominar pai para preencher as condições parentais, é preciso "tornar-se pais" num processo complexo que envolve níveis conscientes e inconscientes do funcionamento mental de ambos os cônjuges. A parentalidade se configura como uma reorganização mental que os pais experimentam e que se inicia com o desejo de ter um filho, ou seja, a parentalidade se refere aos vínculos de parentesco e aos processos psíquicos que surgem a partir do desejo de ter um filho (MACHADO et al, 2015).

Solis-Ponton (2004) assinala que a parentalidade existe desde o surgimento da humanidade e a define como "o estudo dos vínculos de parentesco e dos processos psicológicos que se desenvolvem a partir daí.” (p. 29). A autora aponta, ainda, o narcisismo primário como conceito que define a parentalidade, evidenciando que para ser pai ou mãe é necessário demonstrar aos filhos que são crianças desejadas. 
Maternidade e paternidade são definidas por Safra (2004, p. 128) como “conjunção do momento histórico da família constituída por processos transgeracionais", ou seja, se constitui pelo que é preservado (ou não) pela família em registro transgeracional da memória do ethos humano. A constituição subjetiva de cada um ocorre, sobretudo, através de um outro e do cuidado que esse outro oferece. A partir disso, torna-se relevante pensar sobre como as relações humanas, principalmente as primordiais, são importantes na construção do self. O autor destaca que ser recebido no mundo por um outro é uma necessidade fundamental para o homem. Essa recepção marca o pertencimento à família, à comunidade, além de estabelecer o ethos. As figuras dos cuidadores são de extrema importância para realizar o acolhimento do bebê e apresentá-lo ao mundo. Isso se dará segundo as peculiaridades de cada família, configurando a singularidade desse bebê.

A construção da parentalidade é um processo contínuo, sendo o conhecimento das fantasias, motivações e medos dos pais fundamental para subsidiar intervenções psicoterápicas. No que diz respeito à parentalidade por vias da adoção, não será diferente. Para Morales (2006), imaginar a criança que irá receber é fundamental no processo de aceitação de um terceiro que chegará na vida do casal. Além disso, deve-se assegurar de que a ideia de uma adoção está bem integrada para o casal e, a partir disso, reconhecer quais seriam os medos e os mitos que envolvem o tema.

Assim como numa gestação biológica, na adoção a criança já vem marcada desde sua vida pré-natal pelas expectativas e projeções inconscientes dos pais. A gestação simbólica permite que os pais adotantes sonhem e imaginem o filho, o que será determinante na constituição de sua subjetividade (SCHETTINI, AMAZONAS e DIAS, 2006).

Antes da chegada de um filho, ele já existe no imaginário parental e é circunscrito no inconsciente dos pais por meio de projeções. Com isso, o que é esperado e imaginado sobre o filho adotivo interfere na constituição subjetiva e na forma de existir no mundo. A atenção voltada para esses aspectos da adoção, assim como as motivações conscientes e inconscientes, são importantes para se pensar a assistência dada no momento do preparo para a filiação adotiva (Morelli et al., 2015). 
Segundo Ghirardi (2009), todo projeto de filiação, seja ele adotivo ou biológico, é, por excelência, narcísico, uma vez que os pais depositam nos filhos suas aspirações, frustrações e renúncias. A problemática maior surge quando a criança que irá ser adotada ocupa o lugar de solução para as frustrações dos pais.

As motivações que levam à adoção podem vir carregadas de fantasias que interferem diretamente na construção desse vínculo. De acordo com Gondim (2008), as principais motivações que levam à adoção são: desejo de formar uma família, vontade de ter um filho, ajudar uma criança e dificuldade de engravidar. Refletir sobre as fantasias envolvidas nessas motivações, pode colaborar para a prevenção de frustrações diante daquilo que possa ter sido idealizado sobre a parentalidade.

Rosa (2008) assinala dois lados das fantasias que circundam a adoção. De um lado, fantasias baseadas na idealização dos vínculos familiares, considerando o amor abnegado dos pais adotivos, a gratidão do filho adotivo, e a fantasia de que a família adotiva é especial, um grupo onde reina o amor e o respeito. Por outro lado, temos o preconceito de que essa formação nunca se constituirá como uma família verdadeira e que as crianças possivelmente se tornarão um problema. A autora alerta que, envolvendo esse antagonismo, existe uma gama de fantasias inconscientes em jogo.

Pesquisas apontam para a necessidade de preparação e suporte oferecido às famílias que pretendem adotar (GONDIM et al, 2008; MORALES, 2006; SCHETTINI et al, 2006). O acompanhamento psicológico poderá ajudar no reconhecimento das reais motivações dos candidatos à adoção, discriminando das inconsistentes, que possam atrapalhar o processo. A literatura mostra que, quando os pais não são suficientemente preparados, há o risco da comparação entre o "filho fantasiado" e o "filho real", o que pode gerar frustração no projeto altruísta e levar à depositar o insucesso da adoção na criança.

As frustrações relacionadas à falta de correspondência entre as expectativas parentais e as vivências da adoção acentuam conflitos, que podem tomar proporções extremas e danosas para o vínculo parento-filial. Nesses casos, a devolução da criança aparece como solução e ocorre, geralmente, no período chamado "estágio de convivência". Após ser concretizada a adoção, a devolução passa a ser compreendida, juridicamente, como abandono, devido à irrevogabilidade garantida pelo estatuto legal. Nesse último caso, a devolução é 
tramitada juridicamente, entendendo que a lei nem sempre é capaz de dar conta de certos rompimentos do vínculo afetivo (GHIRARDI, 2009).

Um dos motivos que pode gerar frustração das expectativas, como bem assinalaram Schettini et al (2006), é que muitas famílias adotivas tentam reproduzir a parentalidade e a filiação biológica, negando que estas se apresentam de maneiras diferentes. Deve-se atentar para essa motivação, uma vez que a finalidade da adoção pode ser efetuar uma substituição completa da família biológica pela adotiva. As autoras ressaltam a singularidade identidade e a diferença que configuram uma família construída a partir da adoção. Elas afirmam que a adoção tem uma identidade específica e, como toda identidade, é marcada e constituída pela diferença.

Nos casos onde a motivação surge devido à infertilidade, processos de negação inconscientes dos pretendentes podem dificultar a conscientização dos pais sobre a adoção. Isso porque, na maioria das vezes, a experiência psicológica vem caracterizada pelo sofrimento, exigindo que essas pessoas redefinam suas identidades e elaborem o luto pelo filho não gerado. A sensação de perda, juntamente com sentimentos de inadequação, tristeza e fracasso, podem repercutir, sobremaneira, no processo de adoção se todas essas questões não forem devidamente trabalhadas (SCHETTINI et al, 2006).

Em muitos casos, a principal motivação se faz pela via da alteridade. A adoção não deve ser concebida como um meio para resolução de problemas sociais, mas como direito da criança ou do adolescente de ter uma família onde possa se desenvolver, seja biológica ou adotiva (GONDIM et al, 2008).

A preparação para a chegada de um filho é um aspecto que precisa de atenção específica e especializada. Refletir a respeito das motivações, medos, expectativas e desejos que envolvem a adoção pode colaborar para que os pais pretendentes tomem consciência dos seus limites e possibilidades, favorecendo a compreensão sobre a construção do vínculo parento-filial. O objetivo deste estudo foi investigar como se dá a vivência da parentalidade na adoção tardia, focalizando motivações, expectativas e a importância das redes familiar e social na construção do vínculo parento-filial. 


\section{1 \\ Método}

Participantes

Foram entrevistados 10 sujeitos independentes, 3 homens e 7 mulheres, pertencentes a 3 famílias monoparentais, 3 homoparentais e 4 heteroparentais, com escolaridade superior, que estão com guarda provisória ou com processo de adoção concluído. No caso dos pais com guarda provisória, a destituição do poder familiar pode, ou não, ter sido concluída, embora as crianças estejam em processo adoção. Esse tipo de situação ocorre, frequentemente, no estado do Rio de Janeiro. As crianças foram acolhidas pelas famílias com idades que variaram entre dois anos e seis meses e 11 anos, configurando a chamada adoção tardia, anterior ao período da adolescência. Além disso, o processo de adoção, com a guarda provisória, teve início há, no mínimo, seis meses, antes da realização da pesquisa. (Anexo A).

Instrumento

Uma Ficha Biográfica (Anexo B) foi elaborada de maneira a obter dados gerais sobre, os participantes, a configuração familiar e a adoção. Após o preenchimento da Ficha Biográfica pelo entrevistador, foi realizada uma entrevista individual com roteiro semiestruturado (Anexo C), contendo questões abertas, compostas pelos seguintes eixos temáticos: motivação para a adoção; vivências anteriores, familiares e rede; experiências subjetivas da parentalidade, experiência da construção do vínculo, fantasias relacionadas ao filho imaginado.

Procedimentos

Após aprovação do projeto de pesquisa pelo Comitê de Ética em Pesquisa da universidade onde foi desenvolvido, os participantes foram recrutados a partir do contato com os Grupos de apoio à Adoção e, também, por contatos informais em diferentes redes sociais da pesquisadora. As entrevistas foram realizadas em local de preferência do entrevistado, gravadas em áudio, com a devida autorização dos participantes, mediante a assinatura de um Termo de Consentimento Livre e Esclarecido (Anexo D), e tiveram duração média de uma hora. Os nomes dos pais 
utilizados ao longo do trabalho foram devidamente substituídos por nomes fictícios.

O material foi transcrito e submetido ao método de análise de conteúdo, na sua vertente categorial, com a finalidade de investigar, a partir do material discursivo, as significações atribuídas pelas entrevistadas aos fenômenos (BARDIN, 2011). Por meio da técnica categorial, foram destacadas categorias temáticas, organizadas a partir da semelhança entre os elementos contidos no material coletado. Para tal, procedeu-se a uma "leitura flutuante", agrupando-se dados significativos, identificando-os e relacionando-os, até se destacarem as categorias de análise.

O presente trabalho apresenta parte dos resultados de pesquisa ampla, cujo objetivo foi investigar a construção do vínculo parento-filial nas adoções tardias. Nessa pesquisa mais ampla, emergiram sete categorias das narrativas dos participantes: bagagem da criança, pedras no caminho da adoção tardia e adoção mútua, vivência da parentalidade, motivação para adoção, fantasias e expectativas e participação da rede.Para alcançar os objetivos deste trabalho, foram discutidas as quatro últimas categorias. As outras categorias foram discutidas em outro trabalho.

\title{
3.2
}

\section{Resultados e discussão}

\author{
Vivência da parentalidade
}

A maioria dos pais entrevistados destacou como fator marcante no exercício da parentalidade o momento de impor regras e limites.

"Na hora de sair do banheiro e chegar no quarto eu peguei ele no colo e ele se debateu e deu uma cabeçada no meu maxilar. Aquele momento foi um momento decisivo assim, porque foi logo assim que ele chegou, né. Então eu pensei: Meu Deus! Será que eu dou conta, né? E no minuto seguinte eu pensei: dou sim! (risos) E é essa a minha tarefa. Então ali acho que foi um momento marcante, foi um momento onde eu disse: sou mãe e serei mãe para o que precisar, né." (Ana)

"Nossa é um trabalhão! Eu achei que era mais fácil. (risos) Gente eu jurava que era só dar amor (...) tudo errado, não é só isso não, tem a parte que não quer te obedecer, tem a parte que não quer te escutar, tem a parte de que quer fazer mal 
criação. Gente do céu! é muita trabalheira! (...)então ser mãe é muito muito muito muito trabalhoso, mas eu gosto, no final vale a pena." (Vânia)

Costa e Rossetti-Ferreira (2007) assinalam que a principal dificuldade do pai adotivo em desenvolver sua parentalidade com crianças maiores está na contestação das regras e do seu lugar de autoridade. A criança maior já chega com a capacidade de se contrapor e argumentar junto aos pais, o que reflete uma das particularidades desse tipo de adoção. Em contrapartida, nota-se que essa dificuldade circunscreve o sentimento da parentalidade.

A falta de segurança no vínculo, marcada, sobretudo, pela fantasia de que o filho queira retornar à família biológica, demarca a dificuldade na imposição das regras. Isso acentua a problemática da educação e favorece que a criança seja vista como o problema. De acordo com Maux \& Dutra (2010), esse é um dos motivos pelos quais surgem demandas que enchem consultórios de psicólogos.

Além de destacarem a felicidade como um dos principais sentimentos ao se tornarem pais/mães, de um modo geral, receios diante de assumir a responsabilidade inerente ao exercício da parentalidade emergiram nas falas de modo bastante significativo.

"É você olhar pra aquela pessoinha e dizer que ela nasceu pra você e aí você é responsável por ela pela vida toda. Acho que pai é isso." (Mario)

“Olha, ser mãe, se eu falar pra você que é realizar um desejo meu, é mentira. Porque o desejo de ser mãe foi uma coisa que foi surgindo muito aos poucos (...)eu sempre achei que mãe era uma responsabilidade muito grande, dedicava um tempo de entrega muito grande" (Claudia)

Essa última fala remete, também, à percepção de que o processo de construção da parentalidade se desenvolve aos poucos. Nesse sentido, alguns dos entrevistados citaram o "badalar do sino", referido por muitos pais adotivos como o momento em que sentiram ter encontrado o seu filho. Para outros, o vínculo parento-filial foi se delineando de forma gradual como demonstrado nas falas a seguir:

"Então a gente foi instruído pela psicóloga e pela assistente social a falar com todas as crianças, demos docinho pra todo mundo. Só que ali já se formou um vínculo, assim, fantástico.” (Mario) 
"No final, assim, a gente não sabe em que momento o vínculo acontece, mas ele acontece. Não é coisa de sininho não, porque não bate o sininho, pelo menos pra mim não bateu. É uma coisa construída no dia-a-dia." (Ana)

“O vínculo é feito dentro de casa(...) E o vínculo também não é uma coisa automática porque as pessoas me perguntaram até lá no Grupo de Adoção: 'ah, teve sininho badalando quando você viu o T?' Não, o T pra mim era uma criança como qualquer outra que tava ali no grupo. Não teve sininho e nem nada." (Sara)

Além do caráter gradual, nas adoções tardias existe a especificidade da criança já se posicionar na relação de forma mais ativa que um bebê. Nesse tipo de adoção, a criança é capaz de negociar a afetividade e estabelecer o amor filial. Desta forma, a criança se coloca diante da construção do vínculo e é possível notar a mutualidade dessa construção (COSTA \& ROSSETI-FERREIRA, 2007)

A consciência da parentalidade ficou marcada nas falas como algo que só é possível, na medida em que se exerce a parentalidade.

\begin{abstract}
"Eu acho que é o exercício mais difícil e mais desafiador de reforma íntima que eu tive durante toda minha vida. Não tem como você entender o que é ser mãe antes de ser mãe. Nem pelo lado dos desafios, quanto pelo lado da gratificação que traz." (Ana)
\end{abstract}

"Porque agora vai ser meu. Todo mundo... eu to no comando, eu tomo decisões, eu consigo guia-lo no caminho que eu quero (..)é difícil você explicar o que é ser pai, só sendo pai e mãe né, na verdade, acho que só sendo.” (André)

Ser chamado pela criança de pai/mãe foi referido como momento marcante, ou até mesmo inaugural, na vivência da parentalidade.

\begin{abstract}
"A primeira vez que eu senti que realmente eu ia ser pai foi um dia que, eu já falei com ele, eu ia adotá-lo e ele me chamava de tio. E um dia eu fui levar ele de volta para o abrigo, num domingo à noite, aí ele desceu do carro comigo, do taxi e tal, entrou no abrigo, aí a porta fechou, botou cadeado lá no abrigo e tal. Aí ele voltou pro pátio e falou assim: 'tchau pai!' E entrou. Aí eu parei e falei, gente! É, Agora é pra valer." (André)
\end{abstract}

Motivação para adoção

Pôde-se observar nas falas da maioria dos entrevistados que o que levou à adoção foi o desejo de vivenciar a parentalidade, impossibilitada não apenas pela infertilidade, mas por outras questões como, por exemplo, doença que dificultaria 
a gestação. Ademais, alguns manifestaram desejar ter um filho sem necessariamente ter um parceiro e desejo de constituir uma família, corroborando com os dados apresentados por Gondim et al (2008).

\footnotetext{
"Então eu sempre tive muito na cabeça que paternidade era uma coisa simbólica, então eu nunca tive o desejo de ter um filho biológico, porque eu sabia que não ia ter um filho com uma mulher." (Lucas)

"Na verdade eu comecei a fazer os exames para tentar engravidar e aí eu descobri que eu tinha uma questão de é... uma tendência para trombose, né. E aí eu teria que tomar os remédios anticoagulantes durante toda a gravidez. Só que eu tenho um histórico de doença autoimune (...)E aí o K, meu marido, falou: olha, a gente tem uma relação tão boa, não queria arriscar isso e, e, acho que a gente devia adotar." (Ana)
}

A literatura aponta como principal motivo para adoção a infertilidade de um ou ambos os cônjuges. Schettini et al, (2006) assinalam que a não possibilidade de gestar um filho por vias biológicas deve ser seguido de um luto e aceitação da perda do filho biológico. É preciso passar pela elaboração do luto e substituir o desejo de gerar pelo desejo de ser pai e ser mãe.

A adoção a partir da infertilidade se configura como uma alternativa para a frustração imposta e passa a ser cogitada diante das impossibilidades que demarcam perdas e incapacidades. Esse tipo de motivação favorece que a adoção venha acompanhada por sentimentos depreciativos e da abertura de uma ferida narcísica. Quando a vivência subjetiva da adoção se dá dessa forma, os conflitos a partir da convivência com a criança e que são inerentes a qualquer relação humana serão experimentados como enorme frustração, levando a sentimentos como ódio e rejeição. Por isso, destaca-se a importância de realização do luto do filho biológico para que o filho adotivo não permaneça como aquele que representa a tentativa de sutura da ferida narcísica e como sombra daquele que seria o filho ideal (GHIRARDI, 2009).

Foi possível observar na fala de Laura que o desejo pela adoção surgiu para realizar o sonho de ter uma menina e, também, para ajudar alguém, como um dia tinha sido ajudada:

"E aconteceu que nos quatro anos depois que o meu filho nasceu eu voltei a ter uma doença que acabou tirando meu útero fora e essa decisão foi condicionada a eu ter outra criança. Eu falei com meu marido: olha só, eu queria ter mais uma 
criança pra ver se vinha uma menina, mas como o meu útero não tá dando eu vou tirar, mas você se compromete comigo em adotar uma menina?" (Laura)

"Eu fui uma menina pobre ajudada por alguém e tinha uma vontade de ajudar outra criança pobre. Eu tinha vontade de ajudar, mas a criança não queria ser ajudada. (...)na verdade eu criei uma expectativa altíssima pra mim, por eu ser Assistente Social da Vara da Infância, do Tribunal de Justiça, responsável pelo programa de adoção da minha cidade. Mas ao mesmo tempo eu me sinto muito vitoriosa, sabe, porque eu acho que qualquer pessoa no meu lugar já teria desistido mais rápido." (Laura)

Machado et al. (2015) assinalam que quando a motivação aparece de forma secundária, ou seja, para suprir o desejo primário de, por exemplo, substituição de um filho morto, superação da ferida narcísica da infertilidade ou o exercício da filantropia, aumentam as possibilidades da saúde familiar ficar comprometida. Essa motivação secundária pode ter colaborado para a dificuldade na construção do vínculo parento-filial no caso de Laura, uma vez que, não correspondendo às expectativas, os conflitos foram se instaurando de forma cada vez mais intensa.

O altruísmo como motivação para adoção emergiu de forma direta e indireta para outros participantes:

\footnotetext{
"A gente percebeu que a gente tinha alguma dificuldade pra engravidar novamente, né, e aí a gente decidiu... os médicos recomendaram a gente fazer a inseminação artificial e a gente decidiu, achou melhor fazer a adoção. (...)até pela nossa religião que sempre incentivou, né, a fazer... também assim, procurar ajudar o próximo.” (Sara)
}

"Minha vida inteira eu sempre me preocupei muito com essas crianças, adolescentes, que as vezes não tem chance na vida. E eu pude ajudar um. Que não foi uma ajuda, eu busquei um filho e com isso eu tirei um... eu dei uma chance pra uma criança ter uma família e ter um futuro melhor." (André)

Quando a motivação se dá por altruísmo, numa tentativa de "salvar" a criança abandonada, o estabelecimento de leis e limites fica fragilizado, intensificando-se os conflitos. Os pais esperam que este filho se mostre grato à sua boa ação e, nesse sentido, criam expectativas irreais para o comportamento dessa criança (GHIRARDI, 2009).

Ebrahim (2001) constata que os adotantes tardios são, em sua maioria, mais altruístas que os convencionais e que a motivação para esse tipo de adoção está diretamente ligada à personalidade dos pais adotantes. Esse dado justifica a 
motivação por esse tipo de adoção que se dá, sobretudo, pela preocupação em atender às necessidades do outro, segundo dados da mesma pesquisa.

Com relação à motivação para adoção tardia, os entrevistados destacaram a não necessidade de ter um bebê, principalmente devido ao trabalho e dedicação que este requer, ou por já terem passado por essa experiência, no caso dos participantes com filhos biológicos. Essa motivação pareceu também relacionada à conscientização sobre adoção tardia e ao perfil das crianças abrigadas, na maioria, crianças maiores de três anos.

"Não tenho paciência com bebê, eu acho muito fofo, muito bonito, até os dois primeiros segundos quando começa a chorar e não dormem a noite. Então por essa razão, e pela vida que eu já tenho, que é muito atribulada, eu tenho trocentos mil compromissos, eu não queria abrir mão nem de uma coisa e nem de outra, então eu optei por uma criança um pouco mais independente.” (Vânia)

"O nosso primeiro perfil traçado seria de um a quatro anos, só que no Grupo de Adoção eles falavam que as crianças continuavam nos abrigos depois de certa idade, que ninguém queria e isso mexeu muito com a gente, principalmente com o meu marido.(...) e aí a gente decidiu aumentar essa idade pra dar uma chance maior pra uma criança. Então nosso perfil inicial era de zero a quatro anos, né, depois a gente mudou de zero a sete." (Fernanda)

A literatura aponta que, em geral, a preferência de escolha para adoção de bebês se justifica pela ilusão de que são mais fáceis de serem moldados. Já a opção pela adoção tardia vem de casais que já passaram pela experiência parental, indivíduos solteiros, divorciados e viúvos que não possuem disponibilidade ou desejo de cuidar de um recém-nascido (Costa \& Rossetti-ferreira, 2007; Ebrahim, 2001).

A conscientização dos participantes a respeito do perfil das crianças disponíveis para adoção corrobora com a pesquisa realizada por Queiroz \& Brito (2013). As autoras afirmam que a mudança de perfil se deve à sensibilização e aos esclarecimentos dados aos pretendentes, que favorecem a compreensão sobre o processo de adoção. A flexibilização do perfil, identificada mais recentemente, faz pensar a respeito da eficácia do trabalho realizado por profissionais junto aos pretendentes e da divulgação de resultados de novos estudos sobre o tema, que contribuem para a difusão da nova cultura da adoção. 
O medo de não conseguir se tornar bons pais e boas mães apareceu no discurso dos entrevistados como uma das principais fantasias relacionadas à parentalidade adotiva. Esse temor emergiu ainda mais intensamente, quando atrelado à fantasia de que, se a parentalidade não fosse exercida impecavelmente, aumentaria a possibilidade de retorno da criança para família biológica.

"E é engraçado porque assim, é um momento de muito medo, eu acho porque no Rio de Janeiro eles tem um hábito de colocação das crianças em famílias substitutas antes da destituição do poder familiar (...)Só que é um momento de muito medo porque eu brinco que toda mãe pode errar, menos a mãe substituta. A mãe substituta não pode errar porque a sensação que eu tinha era de que num estudo psicossocial se eu não fosse aquela mãe perfeita isso ia servir de subsídio para que eles voltassem pra família biológica.” (Ana)

De acordo com Huber \& Siqueira (2010), o processo de parentalidade adotiva se mostra dificultado por diversos motivos, dentre eles, o sentimento de estar sendo julgado em seu papel parental por outras pessoas, outros pais, inclusive os biológicos da criança. A construção e internalização da identidade de pais será um processo intenso para os pais adotantes e que irá legitimar o direito de exercer a parentalidade do filho adotivo.

A morosidade dos processos judiciais na adoção favorecem o surgimento do temor do reaparecimento da família biológica, um fantasma que assombra os pais que dão início ao processo. Os processos demoram em média de quatro à cinco anos para serem concluídos, já que correm paralelamente com o processo de destituição do poder familiar. Como a prioridade imposta pelo ECA (BRASIL, 1990) é a manutenção e recuperação da família, são realizadas diversas tentativas de contato com a família biológica até que se entenda que todas as possibilidades foram esgotadas e que a criança seja encaminhada para adoção. Diante disso, muitas famílias adotivas permanecem apenas com a guarda provisória da criança até que a destituição seja concluída, como foi o caso de alguns dos entrevistados. Esse fantasma apareceu nas falas, sobretudo direcionado à figura da mãe biológica, como no caso de Julia:

"Cada vez que tinha que pisar na Vara da Infância, parecia que eu ia encontrar a mãe dela, sem nem saber a cara da mãe dela. Mas tinha aquela sensação de e se ela aparecer aqui no mesmo dia que eu? (...)Então esse medo era muito grande, assim, quem garante que se essa mulher aparecer o juiz não vai mandar voltar pra 
ela? (...) eu falava que não era nem fantasma, eu falava que era uma nuvem negra pairando pela cabeça, sabe aquela nuvenzinha de desenho animado que fica andando com você? Então, eu sentia isso. Uma nuvenzinha e ela pode sair raios ou trovões a qualquer momento, caso a mãe resolvesse surgir." (Julia)

Ladvocat (2002) assinala a competição imaginária que muitas vezes é travada entre a mãe adotiva e a mãe biológica. Nesses casos, a mãe adotiva se percebe como cuidadora e protetora, enquanto a mãe biológica ocupa o lugar do abandono. Assim, haveria oscilação afetiva, por parte da criança, em direção aos pais adotivos e biológicos, ou seja, algumas vezes rejeita os pais biológicos, em outras, rejeita os pais adotivos. Isso ficou evidente nas falas de algumas mães ao mencionarem a mãe biológica:

"A Conselheira Tutelar disse pra mim o seguinte: 'ah, eu perguntei quem é a pessoas que ela mais ama nessa vida e ela disse que foi você, que era você, 'a minha mãe'. E quando eu perguntei quem ela odeia mais nessa vida ela disse que era você também.' Então assim, é uma relação meio estranha, sabe? (...) Então assim, ela tem uma raiva muito grande da mãe. A (psicóloga) diz que todo esse comportamento que ela tem comigo é ainda raiva que ela desconta em mim ainda de tudo que ela viveu com a mãe.” (Laura)

“A relação entre eu e ela é uma relação meio que a distância, eu cheguei a conclusão que ela não gosta muito de mim porque eu lembro a mãe dela (...) 'Mãe Vânia, eu vou te botar num asilo.' Ah, vai? Que bacana! 'É, você me abandonou!' Eu não te abandonei nada! Ela faz essa relação de mim com a (mãe biológica) o tempo todo" (Vânia)

"Eu achei que eles iam fazer o vínculo comigo antes de fazer o vínculo com o P. mas descobri que não é nada disso não. Eles fizeram um vínculo muito mais rápido com o K.(...) tem gente que diz que a raiva materna, né, que a raiva do abandono, que eles carregam isso com eles." (Ana)

Para Schettini et al (2006), comumente os pais adotivos irão nutrir a fantasia de que seus filhos irão abandoná-los movidos pela força do laço sanguíneo e pelo desejo de conhecer a família biológica. O medo do vínculo da criança com a mãe biológica foi evidenciado nas falas dos entrevistados. Foi possível observar na fala de uma mãe, o medo de que seus filhos buscassem conhecer os pais biológicos, criando para si uma defesa, acreditando que por terem sofrido na família biológica, eles nunca irão querer retomar o antigo contato.

"A pessoa sempre acha que na adoção tardia a criança vai considerar muito os biológicos. Não. Eu acho até que eles consideram muito mais a gente. Eles não 
vão querer saber dos biológicos quando eles ficarem grandes, diferente do pequeno que pode querer saber." (Claudia)

A curiosidade da criança com relação aos pais biológicos pode ser percebida pelos pais adotivos como uma avaliação e surge o sentimento de não suficiência, de que falharam no papel de pais. Esse sentimento pode estar alicerçado na noção de que os laços sanguíneos são indissolúveis e os únicos “verdadeiros". (HUBER \& SIQUEIRA 2010),

O fantasma da mãe biológica que emergiu nos discursos dos entrevistados, remete à "fantasia de roubo" por parte da mãe biológica, comum em alguns casos (LEVINZON, 2000). Essa fantasia pode ter efeitos drásticos na medida em que pode gerar ansiedades persecutórias e insegurança diante do amor do filho, atrapalhando a legitimação da filiação.

Para Machado (2014), essas fantasias estão relacionadas às fantasias infantis de roubo de bebês de suas próprias mães. Desta forma, pode-se dizer que as consequências psíquicas não se referem apenas à adoção, mas a questões bastante primitivas de cunho edípico.

Outro medo evidenciado nas falas, foi o de ter escolhido o filho errado, haja vista a possibilidade de escolha que se apresenta nas adoções.

“Ah meu Deus! Será que se tivesse adotado outro seria melhor? Seria pior? Porque passa essas coisas pela cabeça, não sejamos hipócritas (risos). Será que se fosse filho biológico iria passar por essas dificuldades? Tudo isso passa na sua cabeça. Passa um milhão de dúvidas, um milhão de perguntas como ainda hoje passa, ainda penso, será que to fazendo o melhor?" (Sara)

"Como que eu vou saber que essa criança é o meu filho? O que que vai me dizer que é a criança que é o meu filho? Eu tinha muito medo disso. Um medo bobo, mas assim, será que eu vou pegar a criança errada, será que eu vou escolher errado? E no fundo não tem escolha, na verdade não tem escolha. Isso me falaram assim, olha, quem escolhe não é você, quem escolhe são eles." (André)

Ao confrontar as expectativas com a realidade do dia-a-dia, alguns entrevistados demonstraram a diferença entre a idealização da parentalidade e a convivência com o filho da realidade:

"Como é que eu achava? Ah, tava no mundo de Bob! (risos) Eu achava que só ia ouvir aquela frase: ah, mamãe eu te amo! Mamãe eu sou feliz! Mamãe muito obrigado! Mamãe, você é o amor da minha vida! Engraçado, né, que você cria a 
tal da expectativa e depois vem a realidade e quando as duas se colidem é um estresse só!(...) a gente cria umas expectativas horrorosas." (Vânia)

"Eu tinha expectativa de que eu ia ser a mãe perfeita, que eu não ia errar nunca, que eu ia ser diferente (...), que eu ia ser diferente das minhas amigas, que eu ia conseguir colocar limites com assertividade(...) Hoje eu sou uma mãe muito mais imperfeita, mas muito mais mãe também do que aquela que eu idealizei, eu acho. (...)Eu já tinha, não tinha muitas expectativas, não tinha romance e ainda assim eu te digo, todas as minhas expectativas foram por água abaixo." (Ana).

Além das expectativas dos pais, existem também as expectativas da criança que passa a ter uma nova família. Isso foi mencionado por alguns dos entrevistados, destacando a frustração das expectativas criadas pela criança. Elas acabam, de certa forma, idealizando uma família perfeita como forma de reparar os sofrimentos do passado.

"Ele achou, não sei se foi no abrigo que falaram isso pra ele, que quando ele tivesse uma família ele ia poder fazer tudo aquilo que ele quisesse. E quando ele chegou aqui não era bem assim, até porque eu sempre fui muito regrada.” (Sara)

"Ela achou que tipo, ela ia entrar na minha casa um dia e ia parar os pesadelos dela no dia seguinte. Então foi muito complicado lidar com essa frustração dela." (Claudia)

"Logo assim que ele veio, ele tinha uma fantasia de ser rico, de ter pais ricos e isso obviamente não aconteceu porque a gente não é, mas ele vinha com todas essas ideias e eu acho que isso frustrou ele inicialmente porque não ia ser rico." (Lucas)

\section{Participação da rede}

Nas falas dos entrevistados, o suporte oferecido pela rede familiar, social e profissional foi fundamental para o bom andamento do processo de adoção. A aceitação da família emergiu como fator de grande importância, mesmo quando a reação inicial dos familiares não foi muito favorável.

\footnotetext{
"Mas assim, de repente numa família não tão estruturada, teria sido mais difícil, talvez. Se a gente não tivesse união suficiente, se não fosse o casamento de pessoas já maduras, que talvez se fosse o casamento de pessoas mais imaturas não ia aguentar a bola. Então assim, a gente tinha o entrosamento bom, minha irmã ajudando, minha mãe ajudando, todo mundo ali em volta." (Fernanda)
}

"De imediato a família inteira acolheu muito bem, é uma decisão sua, vamos apoiar porque é o que você quer, é o filho que você vai ter." (André) 
"Quando eu disse que eram três ele ficou extremamente assustado e meu irmão também, pela quantidade, né. Mas eles lidam muito bem, adoram as crianças, não tem nenhum problema por causa da adoção.” (Mario)

A rede social é de extrema importância para a manutenção do equilíbrio familiar e não se restringe à família nuclear ou extensa (SLUZKI, 1997). Nas falas dos participantes, a relação com amigos e vizinhos se mostrou atravessada pelo olhar direcionado à caridade, sendo encarados como super-heróis por terem adotado. Isso demonstra o quanto a adoção ainda é tida como um ato altruísta para a grande maioria das pessoas.

"No fundo eu fico até meio constrangida porque todo mundo me acha uma heroína, uma irmã de caridade que tá fazendo um favor muito grande pra essas crianças. Ninguém vê que as crianças fazem muito mais pela gente do que a gente por elas, né. Porque ela me possibilitou realizar minha maternidade e ao meu marido a paternidade." (Claudia)

"Nos vizinhos tem a questão de adotar quatro, né. A gente já se torna um superherói pra todo mundo, né. (...) As pessoas admiram a gente por isso, né.” (Mario)

Alguns entrevistados destacaram o questionamento, por parte da família e amigos, com relação ao desejo de concretizar a adoção. Em todos os casos, os participantes se posicionaram de forma assertiva e não se deixaram influenciar pelos questionamentos baseados em preconceitos, como é possível notar nas falas das mães a seguir:

"Ela veio me questionar como que eu tinha certeza que eu ia amar aquela criança. Isso pra mim foi uma facada, né. Eu falei assim, da mesma forma que eu amo várias crianças que jamais vão ser meus filhos.” (Julia)

"Uma vez, o meu avô me disse: mas minha filha, você não que mesmo filhos que sejam seus, seus né? Aí eu virei pra ele e disse: oh vô, mas meus filhos vão ser meus, meus." (Ana)

Essa última fala demonstra ainda, como a influência dos familiares não teve caráter decisivo para a escolha da adoção, corroborando com a pesquisa de Machado et al (2015), sendo o fator principal para a adoção o próprio desejo dos entrevistados. Todavia, a partir do momento em que houve a inclusão da criança na família, o papel da família extensa se mostrou significativo, como pode se observar na fala de Mario: 
"Mas depois, agora né, tem os netos agora que vão tomar banho na casa da vovó, banho de mangueira, de piscina, vão almoçar. Hoje em dia não tem problema algum. Mas no início foi um pouquinho essas questões, né. Essa resistência por parte da minha mãe.” (Mario)

Foi possível observar nas falas dos participantes que a rede profissional de apoio foi de grande importância na preparação para adoção, bem como para a manutenção do processo diante de todos os obstáculos que surgem nas fases que o compõem.

"E eu já sabia, mas desde o início eu já busquei ajuda, desde o início que eles tem psicólogo, psiquiatra, fonoaudiólogo, eles tem tudo isso desde o início. Eu falo que é a equipe que me ajuda em todo esse período de adaptação." (Claudia)

"Eu precisei de muito apoio emocional, eu faço terapia, meus filhos fazem terapia, eu precisei da minha família presente. Então assim, eu precisei de muito amparo pra me manter firme e pra não titubear nessa certeza que eu tenho de que sou mãe deles." (Ana)

Careta \& Motta (2008) assinalam a necessidade do acompanhamento psicológico tanto dos adotantes quanto da criança com prioridade durante o pós adoção, no período de guarda provisória, quando surgem os principais desafios de convivência. Tanto a criança quanto quem adota precisa passar pela adaptação, o que as autoras chamam de "construir abruptamente uma relação familiar" (p.37). Nota-se, portanto, a importância dos esclarecimentos oferecidos aos pretendentes à adoção, principalmente no que diz respeito à quebra de idealizações associadas ao interesse pela adoção. Adotar uma criança significa adotar também os problemas e dificuldades que acompanham a experiência de separação do lar biológico.

\section{3}

\section{Considerações finais}

A adoção, na maioria das vezes, se dá no encontro de dois sofrimentos: a perda dos laços primários de uma criança e a desilusão de um casal diante da não possibilidade de gerar filhos. Nesse sentido, ela representa a saída para que a criança possa restituir o ambiente familiar que favoreça seu desenvolvimento, 
espaço para trocas afetivas e possibilidade de reconstruir o que antes possa ter se mostrado negligente ou faltoso. Por outro lado, a adoção também representa possibilidade de exercício da parentalidade, sejam quais forem as motivações que levam a essa escolha.

Os resultados dessa pesquisa evidenciaram que a motivação para a adoção surge através do desejo de ter filhos, podendo estar marcada pela infertilidade ou pelo altruísmo. Quanto à infertilidade, é importante salientar que a substituição do filho biológico pelo filho adotivo pode representar uma forma de lidar com a experiência de um luto não elaborado, na tentativa de encobrir uma ferida narcísica diante da impossibilidade de gestação. A motivação por altruísmo pode culminar na expectativa frustrada de que o filho corresponda com gratidão ao bem que lhe foi feito. Em ambos os casos, podem ocorrer efeitos danosos, diretos na construção do vínculo parento-filial, na medida em que as expectativas desse filho vir a preencher e suturar essa ferida não são alcançadas.

A rede de apoio surge como fundamental no que diz respeito à colaboração para o bom andamento do processo. Apesar de haver preconceitos arraigados envolvendo o tema da adoção, muitas vezes revelados em falas, olhares e ações, de alguns membros dessa rede, o suporte e o apoio oferecidos pela maioria colabora para a construção e manutenção do vínculo. Isto se evidencia, sobretudo, quando a criança passa a ser integrada à rede, seja familiar ou social. Para tanto, o trabalho da rede profissional é essencial em todas as etapas desse processo, como foi destacado pelos participantes dessa pesquisa.

Refletir a respeito da configuração familiar a partir da adoção, considerando as especificidades que envolvem o desejo da família e as necessidades da criança, e investigar elementos inerentes ao suporte indispensável para pessoas que buscam ocupar o lugar de pais e/ou mães pela via da adoção se faz condição sine qua non para lidar com os desafios contemporâneos da parentalidade.

Portanto, faz-se necessário ampliar os estudos com ênfase nas famílias constituídas por adoção. A atenção para as experiências subjetivas dos pais adotivos, seus medos, fantasias, expectativas e motivações é fundamental para favorecer o exercício da parentalidade e para que a criança tenha garantido seu direito de pertencer à uma família que lhe proporcione ambiente suficientemente bom para seu desenvolvimento. 


\section{4.}

\section{Considerações finais}

Nas adoções consideradas tardias, ou seja, de crianças maiores de dois anos, existem diversas especificidades que merecem atenção. Tanto os pais quanto as crianças passarão por desafios importantes na construção do vínculo parentofilial. Principalmente por se tratar de adoção de criança com idade mais avançada, ela trará consigo vivências anteriores desde a família de origem, incluindo a passagem por abrigos, de acordo com a singularidade da história de cada uma.

Os resultados da pesquisa demonstraram a relevância da atenção dada ao histórico da criança. Na maioria dos casos, o medo da interferência de costumes que possam vir junto com o filho adotivo emergiu como um fantasma no momento da escolha do perfil de uma criança mais velha. O preparo realizado no sentido de esclarecer e quebrar alguns estigmas sobre adoção tardia foi fundamental para os encaminhamentos futuros do processo de adoção de todos os entrevistados.

A bagagem de vivências que a criança carrega consigo pode vir carregada de experiências que marcarão dificuldades para o período de adaptação e construção do vínculo parento-filial, sobretudo nos casos que envolvem traumas anteriores. Faz-se importante a legitimação do passado do filho adotivo, principalmente para compreender suas necessidades e poder ressignificar falhas do passado. A história da criança não deve ser descartada, mas integrada à história da nova família, para dar novos sentidos ao que de ruim possa ter ficado marcado e legitimar o que ficou de bom. Desta forma, a família adotiva se apresenta como espaço potencial para elaborações.

Dentre as principais dificuldades destacadas pelos entrevistados estão: adaptação à rotina familiar envolvendo a imposição de regras e limites, lacunas no que diz respeito à aprendizagem formal, comportamento agressivo e falta de segurança jurídica. Pode-se dizer que as famílias enfrentarão desafios externos que dizem respeito ao preconceito e estigma ainda presentes na sociedade, além dos desafios na relação do dia-a-dia. Quanto ao último, é importante salientar que o momento da construção do vínculo é também o momento de testagem do ambiente por parte da criança. Diante de uma história que, muitas vezes, demarca 
perdas e separações, a criança irá testar o ambiente para ter certeza de que a nova família será capaz de sobreviver e suportar tudo de negativo que possa vir dela, para só depois obter a certeza de que pode ser amada.

A forma como cada pai/mãe irá lidar com esses desafios, de forma singular, será fundamental para o bom andamento do processo. Para tanto, a subjetividade dos pais, seus medos e expectativas entrelaçados ao desejo de ter um filho compõem a transição para a parentalidade, marcada pelas motivações de cada um. Nos relatos dos entrevistados foi possível notar que a motivação para adoção se deu, principalmente, pelo desejo de ter filhos e construir família. Esse desejo pode vir marcado pela infertilidade ou pela intenção altruísta. Desta forma, a frustração das expectativas possui grandes chances de ser vivenciada, sobretudo se a idealização do filho estiver sobreposta ao filho da realidade.

Todo projeto parental envolve idealizações do filho esperado. É preciso imaginar o filho para começar a inseri-lo na dinâmica parental. Contudo, quando as expectativas são fundamentadas unicamente pela intenção de tamponar uma ferida narcísica, seja pela impossibilidade de gestar um filho biológico ou pelo desejo de fazer o bem, esperando salvar uma criança, as possibilidades de frustração e de conflito na relação se veem aumentadas.

Para lidar com os desafios contemporâneos no exercício da parentalidade, sobretudo por via da adoção, é preciso atenção às experiências subjetivas dos pais e às vivências da criança. Nesse sentido, o suporte profissional é indispensável para que as famílias não se sintam desamparadas em meio aos desafios dessa construção. A construção do vínculo parento-filial demanda esforço diário, numa construção mútua a partir do encontro de dois sofrimentos. De um lado, a criança que, por algum motivo, não pôde crescer e se desenvolver na família de origem e aguarda a possibilidade de ter uma família que repare o que possa ter havido de ruim em seu passado. Por outro lado, está a família repleta de desejo por vivenciar a parentalidade, na maior parte das vezes, impossibilitada pela infertilidade.

Muitos avanços em direção aos direitos da criança e do adolescente de ter uma família já foram alcançados. Todavia, a atenção dada às famílias que planejam vivenciar a parentalidade por meio da adoção ainda se mostra bastante fragilizada. Portanto, novos estudos que se dediquem à parentalidade adotiva são fundamentais. O número de crianças que habitam os abrigos, no Brasil, é altíssimo, mas o número de famílias em busca de um filho é maior. Algo precisa 
ser feito com relação a essa disparidade. A luta pela disseminação da nova cultura da adoção ainda precisa avançar muito em busca da garantia do direito de que toda criança deve pertencer a uma família que lhe possibilite se desenvolver em meio aos cuidados e afetos indispensáveis para todas. 


\section{5.}

\section{Referências bibliográficas}

ALTOÉ, S.; SILVA, M. M. Características de uma clínica psicanalítica com crianças e adolescentes em situação de vulnerabilidade social. Estilos da Clínica. São Paulo, v.18 n.1, p.125-141, 2013.

AMIM, I. D.; MEANDRO, P. R. M. Preferências por Características do Futuro Filho Adotivo: Manifestadas por Pretendentes à Adoção. Interação em

Psicologia. v.11 n.2, p.241-252, 2007.

BARDIN, L. Análise de conteúdo. Lisboa, Edições 70, 1977.

BAPTISTA, J., SOARES, I. \& HENRIQUES, M. Recuperação desenvolvimental após a adoção: características da criança e da família adotiva. Psicologia:

Reflexão e Crítica. v.26, n.2, p. 396-404, 2013.

BÖING, E.; CREPALDI, M. A. Os efeitos do abandono para desenvolvimento psicológico de bebês e a maternagem como fator de proteção. Estud. Psicol. Campinas, v.21, n.3, p.211-226, 2004.

BRASIL. Lei N. ${ }^{\circ}$ 8.069, de 13 de julho de 1990. Dispõe sobre o Estatuto da Criança e do Adolescente e dá outras providências. Diário Oficial da União, Brasília, DF, 16 set. 1990. Retificado em 27 set. 1990.

BRASIL. Lei $n^{\circ} 12.010$, de 3 de agosto de 2009. Dispõe sobre adoção; altera as Leis nos 8.069, de 13 de julho de 1990 - Estatuto da Criança e do Adolescente. Brasília, DF: Casa Civil, Subchefia para assuntos jurídicos.

CARETA, D. S.; MOTTA, I. F. Daniel e Mathias: retratos de violência e desamparo. In: ROSA, J. T; MOTTA, I. F. (Org) Violência e sofrimento de crianças e adolescentes na perspectiva winnicottiana. P.17-44. São Paulo: FAPESP, 2008.

Conselho Nacional de justiça - Cadastro Nacional de Adoção (CNA), - Relatórios estatísticos. Disponível em:

<http://www.cnj.jus.br/cnanovo/pages/publico/index.jsf> Acesso em 19 de setembro de 2016. 
COSTA, N. R.; ROSSETTI-FERREIRA, M. C. Tornar-se pai e mãe em um processo de adoção tardia. Psicologia: Reflexão e Crítica, v. 20, n. 3, p. 425-434, 2007.

DIAS, C. M. S. B, SILVA, R. V. B., FONSECA, C. M. S. M. S. Adoção de crianças maiores na perspectiva dos pais adotivos. Contextos Clínico. v.1 n.1, p. 28-35, 2008.

EBRAHIM, S. G. Adoção tardia: altruísmo, maturidade e estabilidade emocional. Psicologia, Reflexão e Crítica, v. 14, n. 1, Porto Alegre, 2001.

FERNÁNDEZ, M.; FUENTES, M, J. Como valoran las familias la adopción de niños mayores: Implicaciones para la actuación de los técnicos. Bienestar y Protección Infantil. v. 3, n. 2, p. 97-112, 2004.

GHIRARDI, M. L. A. M. A devolução de crianças adotadas: ruptura do laço familiar. Pediatria Moderna, v. 45, n. 2, p. 66-70, 2009.

GOMES, K. A adoção à luz da teoria winnicottiana. Winnicott e-prints, São Paulo, v.1, n.2 p.51-68, 2006.

GONDIM, A. K. et al. Motivação dos pais para a prática da adoção. Boletim de Psicologia. v.58 n.129, p.161-170, 2008.

LONDEN, W. M.; JUFFER, F; IJZENDOORN, M. H. Attachment, Cognitive and Motor Development in Adopted Children: Short-term Outcomes after International Adoption. Journal of Pediatric Psychology. v.32, n.10, p.12491258, 2007.

MACHADO, R. N.; FÉRES-CARNEIRO, T. Parentalidade e filiação: o que revelam e o que ocultam as narrativas dos pais. Rio de Janeiro, 2014. 172 p. Tese de Doutorado - Departamento de Psicologia, Pontíficia Universidade Católica do Rio de Janeiro.

HOUZEL, D. As implicações da Parentalidade. In: SOLIS-PONTON, L. Ser pai, ser mãe, parentalidade: um desafio para o terceiro milênio. São Paulo: Casa do Psicólogo, 2006.

HUBER, M. Z.; SIQUEIRA, A. C. Pais por adoção: a adoção na perspectiva dos casais em fila de espera. Psicologia: Teoria e prática. v.12, n.2, p.200-216, 2010. LADVOCAT, C. Mitos e segredos sobre a origem da criança na família adotiva. Rio de Janeiro: Booklink, 2002. 
LADVOCAT, C.; FÉRES-CARNEIRO, T. Mitos e segredos sobre a origem da criança na família adotiva. Rio de Janeiro, 2001. Dissertação de mestrado Departamento de Psicologia, Pontíficia Universidade Católica do Rio de Janeiro. LEVINZON, G. K. A criança adotiva na psicoterapia psicanalítica. 2 ed. São Paulo: Escuta, 2000.

LEVY, L.; PINHO, P. G. R.; FARIA, M. M. "Família é muito sofrimento”: um estudo de casos de "devolução" de crianças. Psico. Porto alegre, PUC-RS, v.40, n.1, p.58-63, 2009.

LUZ, A. F.; GELAIN, D.; AMARAL, L. M. Vivências das famílias na adoção tardia. Revista de Psicologia da IMED, v.6 n.1, p. 52-57, 2014.

MACHADO, R. N.; FÉRES-CARNEIRO, T.; MAGALHÃES, A. S.

Parentalidade adotiva: contextualizando a escolha. Psico. Porto Alegre, v.46, n.4, 2015.

MAUX, A., A., B.; DUTRA, E. A adoção no Brasil. Algumas reflexões. Estudo e pesquisa em psicologia. V.10, n. 2, p. 356-372, 2010.

MIRANDA, C. E. S.; COHEN, R. H. P. Uma criança é adotada: O lugar simbólico da filiação e seus efeitos subjetivos. Psicologia em pesquisa, n.6 v.1, p. 61-67, 2012.

MORALES, A. T. Os predicados da parentalidade adotiva. In: SOLIS-PONTON, L. Ser pai, ser mãe, parentalidade: um desafio para o terceiro milênio. São Paulo: Casa do Psicólogo, 2006.

MORELLI, A. B,; SCORSOLINI-COMIN, F.; SANTEIRO, T. V. O" lugar" do filho adotivo na dinâmica parental: revisão integrativa de literatura. Psicologia Clínica, Rio de Janeiro, v. 27, n. 1, p. 175-194, 2015.

OCHOA-TORRES, C.; LELONG, I. A função parental: uma abordagem a partir da teoria do apego. In: Solis-Ponton, L. Ser pai, ser mãe, parentalidade: um desafio para o terceiro milênio. P. 123-131. São Paulo: Casa do Psicólogo, 2006. OTUKA, L. K.; SCORSOLINI-COMIN.; F.; SANTOS, M. A. Adoção suficientemente boa: Experiência de um casal com filhos biológicos. Psicologia: Teoria e Pesquisa, 28(1), 55-63, 2012.

PEITER, C. Adoção,vínculos e rupturas: do abrigo à família adotiva. São Paulo: Zagodoni, 2011. 
QUEIROZ, A. C. A.; BRITO, L. Adoção Tardia: o desafio da garantia do direito à convivência familiar e comunitária. Textos \& Contextos, v.12, n.1, p. 55-67, 2013.

ROSA, D. B. A narrativa da experiência adotiva: fantasias que envolvem a adoção. Psicologia Clínica. Rio de Janeiro, v.20, n.1, p.97-110, 2008.

SAFRA, G. O sofrimento humano e as fraturas éticas. In: SAFRA, G. A po-ética na clínica contemporânea. São Paulo: Ideias e Letras, 2004. P. 127-143.

SCHETTINI, S., S., M.; AMAZONAS, M., C., L., A.; DIAS, C., M., S., B.

Famílias adotivas: Identidade e diferença. Psicologia em Estudo. v.11, n.2, p. 285-293, 2006.

SILVA, M. L.; ARPINI, D. M. A Nova Lei Nacional de Adoção: Desafios para a reinserção familiar. Psicologia em Estudo, Maringá, PR, v.18, n.1, p.125-135, 2013.

SILVA, M. P. O.; GUIMARÃES, F. L.; PEREIRA, S. K. R. Caminhos da Adoção. In: Ladvocat, C. ( org) Guia da adoção: no jurídico, no social, no psicológico e na família. São Paulo, Editora Roca, 2014.

SLUZKI, C. E. A rede social na prática sistêmica: alternativas terapêuticas. São Paulo: Casa do Psicólogo, 1997.

SOLIS-PONTON, L. A construção da parentalidade. In: SOLIS-PONTON, L. Ser pai, ser mãe, parentalidade: um desafio para o terceiro milênio. São Paulo: Casa do Psicólogo, 2006.

VARGAS, M. M. Adoção tardia: da família sonhada à família possível. 2 ed.

São Paulo: Casa do psicólogo, 2013.

WEBER, L. N. D. Famílias adotivas e mitos sobre o laço de sangue. Jornal Contato CRP, v.8, n.79, 1996.

WINNICOTT, D. W. O ódio na contratransferência. In: WINNICOTT, D. W. Da Pediatria à Psicanálise: obras escolhidas. Rio de Janeiro: Imago, [1947] 2000. p. 277-287.

WINNICOTT, D. W. Preocupação maternal primária. In D. W. WINNICOTT . Da Pediatria à Psicanálise: obras escolhidas. Rio de Janeiro: Imago, [1956] 2000 .

WINNICOTT, D. W. Desenvolvimento emocional primitivo. In D. W. WINNICOTT . Da Pediatria à Psicanálise: obras escolhidas. Rio de Janeiro: Imago, [1945] 2000. 
WINNICOTT, D. W. O desenvolvimento da capacidade de se preocupar. In: WINNICOTT, D. W. O ambiente e os processos de maturação. Porto Alegre: Artes Médicas, 1963.

ZORNIG, S. A. J. Tornar-se pai, tornar-se mãe: o processo de construção da parentalidade. Tempo psicanalítico., Rio de Janeiro, v. 42, n. 2, 2010. ZORNIG, S. A. J.; LEVY, L. Uma criança em busca de uma janela: função materna e trauma. Estilos da Clínica. v.11, n.20, São Paulo jun. 2006. 


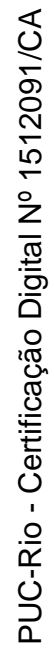
ANEXOS 


\section{ANEXO A}

Tabela dos Sujeitos

\begin{tabular}{cccccc} 
Participante Idade & Profissão & $\begin{array}{c}\text { Configuração } \\
\text { familiar }\end{array}$ & $\begin{array}{c}\text { Idade da } \\
\text { criança } \\
\text { quando } \\
\text { adotada }\end{array}$ & $\begin{array}{c}\text { Idade } \\
\text { atual da } \\
\text { criança }\end{array}$ & $\begin{array}{c}\text { Processo } \\
\text { concluído biológicos }\end{array}$ \\
\hline
\end{tabular}

Ana $\quad 35$ Advogada Heteroparental 2a; 3a 6m 4a; 5a 6m (irmãos)

\begin{tabular}{|c|c|c|c|c|c|c|c|}
\hline André & 47 & $\begin{array}{l}\text { Engenheiro } \\
\text { civil }\end{array}$ & Monoparental & $11 \mathrm{a}$ & $15 \mathrm{a}$ & Sim & - \\
\hline Mario & 39 & Contador & Homoparental & $\begin{array}{l}\text { 11; 2a 6m, } \\
\text { 1a 6m; 3m } \\
\text { (irmãos) }\end{array}$ & $\begin{array}{l}13 \mathrm{a} ; 5 \mathrm{a} \\
3 \mathrm{a} ; 2 \mathrm{a}\end{array}$ & Sim & - \\
\hline $\begin{array}{l}\text { 仓 } \\
\frac{1}{\circ} \text { laudia } \\
\text { D } \\
\frac{1}{n}\end{array}$ & 50 & Professora & Heteroparental & $\begin{array}{l}\text { 6a; 8a } \\
\text { (irmãos) }\end{array}$ & $7 a ; 8 a$ & - & - \\
\hline 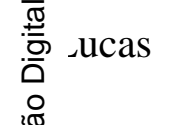 & 38 & Projetista & Homoparental & $\begin{array}{l}\text { 6a; 9a; 11a } \\
\text { (irmãos) }\end{array}$ & $\begin{array}{l}\text { 7a; 10a; } \\
11 \mathrm{a}\end{array}$ & - & - \\
\hline ơ Sara & 44 & Contadora & Heteroparental & $7 \mathrm{a}$ & $10 \mathrm{a}$ & - & - \\
\hline 곳 rnanda & 45 & $\begin{array}{c}\text { Professora } \\
\text { universitária }\end{array}$ & Heteroparental & $\begin{array}{l}\text { 4a; 10a } \\
\text { (irmãos) }\end{array}$ & $5 a ; 11 a$ & - & Sim \\
\hline Julia & 37 & $\begin{array}{c}\text { Consultora } \\
\text { de beleza }\end{array}$ & Monoparental & $2 \mathrm{a} 6 \mathrm{~m}$ & $6 a$ & Sim & - \\
\hline Vânia & 45 & Advogada & Homoparental & $6 \mathrm{~m}, 5 \mathrm{a} ; 12 \mathrm{a}$ & $\begin{array}{l}27 \mathrm{a} ; 12 \mathrm{a} ; \\
16 \mathrm{a}\end{array}$ & Sim & - \\
\hline Laura & 46 & $\begin{array}{c}\text { Assistente } \\
\text { social }\end{array}$ & Monoparental & $9 \mathrm{a}$ & $15 \mathrm{a}$ & Sim & Sim \\
\hline
\end{tabular}




\section{ANEXO B}

\section{Ficha Biográfica}

Entrevista número

Idade:

Escolaridade:

Ocupação:

Religião:

Estado civil: Se casado, quanto tempo?

Possui filho biológico? ( ) Sim ( ) Não Se sim, quantos?

Configuração familiar:

Adotou há quanto tempo? Processo concluído?

Idade da(s) criança no momento da adoção:

Idade atual: 


\section{ANEXO C}

\section{Roteiro semiestruturado}

\section{Motivações para a adoção}

1) O que te motivou a adotar uma criança?

2) O que te levou a adotar uma criança mais velha?

3) Qual era o perfil inicial?

4) O que te fez mudar o perfil?

\section{Vivências anteriores e familiares/rede}

1) Existe algum histórico de adoção na sua família?

2) Como seus familiares lidam com a adoção?

3) Como ficaram suas relações com familiares, amigos, vizinhos após a adoção?

\section{Experiências subjetivas da parentalidade}

1) O que é ser pai/mãe para você?

2) Houve alguma situação que você destacaria como marcante na experiência de ser pai/mãe?

\section{Experiência de construção do vínculo}

1) Como foi o período de adaptação?

2) Quais foram as principais facilidades e dificuldades encontradas na relação do dia-a-dia?

3) Como as vivências anteriores do seu filho influenciaram a relação entre vocês?

\section{Fantasias relacionadas ao filho imaginado}

1) Como você esperava que fosse a experiência de ser pai/mãe antes de concretizar a adoção?

2) Como você imaginou que fosse se dar a relação entre vocês?

3) Quais foram seus sentimentos ao adotar?

4) E hoje? O que aconteceu com essas expectativas?

Gostaria de acrescentar algo? Alguma coisa que você ache importante? 


\section{ANEXO D \\ Pontifícia Universidade Católica $_{\text {and }}$ DO RIO DE JANEIRO}

Termo de Consentimento Livre e Esclarecido (em duas vias)

Instituição de origem: Pontifícia Universidade Católica do Rio de Janeiro

Título da pesquisa: "A construção do vínculo parento-filial nas adoções tardias"

Pesquisadora: Débora da Silva Sampaio

E-mail: deborasampaio@ rocketmail.com

Telefone: 21993085803

Orientadora: Andrea Seixas Magalhães

Telefone: 2135271185

E-mail: andreasm@puc-rio.br

Você está sendo convidado a participar de uma pesquisa por meio da qual pretendemos compreender melhor a construção do vínculo parento-filial nas adoções tardias. Esta pesquisa será realizada por meio de uma entrevista gravada e, posteriormente, transcrita, permanecendo sob a responsabilidade da pesquisadora todo e qualquer dado de identificação. Todas as informações têm caráter confidencial, portanto sua identidade será mantida em sigilo.

Sua participação é voluntária, estando livre para interromper a entrevista quando assim desejar; fazer as perguntas que julgar necessárias; recusar-se a responder perguntas ou falar de assuntos que lhe possam causar qualquer tipo de constrangimento. A participação nessa pesquisa não traz qualquer risco à saúde, podendo apenas gerar certa timidez ao longo da entrevista. Em caso de constrangimento, a entrevista poderá ser interrompida por pedido do entrevistado.

Com sua adesão, você estará contribuindo para conhecermos mais sobre as experiências na construção do vínculo entre pais e filhos nas adoções hoje. Assinando este termo de consentimento, você estará autorizando a pesquisadora a utilizar em ensino, pesquisa e publicação, as informações prestadas na entrevista, sendo preservada sua identidade e a dos membros da sua família. Um exemplar deste Termo de Consentimento Livre e Esclarecido, devidamente assinado, ficará com o entrevistado e outro com a pesquisadora.

Assinatura da Pesquisadora

Débora da Silva Sampaio
Assinatura do entrevistado

Rio de Janeiro, 